\title{
Cyanthiwigin Natural Product Core as a Complex Molecular Scaffold for Comparative Late-Stage C-H Functionalization Studies
}

\author{
Kelly E. Kim, ${ }^{\dagger}$ Ashley M. Adams, ${ }^{\ddagger}$ Nicholas D. Chiappini, ${ }^{\ddagger}$ J. Du Bois, ${ }^{\ddagger}$ and Brian M. Stoltz ${ }^{* \dagger \odot}$ \\ ${ }^{\dagger}$ Division of Chemistry and Chemical Engineering, California Institute of Technology, Pasadena, California 91125, United States \\ ${ }^{\ddagger}$ Department of Chemistry, Stanford University, Stanford, California 94305, United States
}

\section{Supporting Information}

ABSTRACT: The desire for maximally efficient transformations in complex molecule synthesis has contributed to a surge of interest in C$\mathrm{H}$ functionalization methods development in recent years. In contrast to the steady stream of methodological reports, however, there are noticeably fewer studies comparing the efficacies of different $\mathrm{C}-\mathrm{H}$ functionalization protocols on a single structurally intricate substrate. Recognizing the importance of heteroatom incorporation in complex molecule synthesis, this report discloses a comparative examination of diverse strategies for $\mathrm{C}-\mathrm{O}, \mathrm{C}-\mathrm{N}$, and $\mathrm{C}-\mathrm{X}$ bond formation through late-stage $\mathrm{C}-\mathrm{H}$ oxidation of the tricyclic cyanthiwigin natural product core. Methods for allylic $\mathrm{C}-\mathrm{H}$ acetoxylation, tertiary $\mathrm{C}-\mathrm{H}$ hydroxylation, tertiary $\mathrm{C}-\mathrm{H}$ amination, tertiary $\mathrm{C}-\mathrm{H}$ azidation, and secondary $\mathrm{C}-\mathrm{H}$ halogenation are explored. These efforts highlight the robustness and selectivities of many well-established protocols for $\mathrm{C}-\mathrm{H}$ oxidation when applied to a complex molecular framework, and the findings are relevant to chemists aiming to employ such strategies in the context of chemical synthesis.

\section{INTRODUCTION}

The selective functionalization of unactivated $\mathrm{C}-\mathrm{H}$ bonds is one of the foremost challenges in synthetic chemistry today. ${ }^{1}$ $\mathrm{C}-\mathrm{H}$ bonds are ubiquitous in organic molecules, and the direct conversion of these traditionally inert moieties to other functional groups has the potential to streamline synthetic strategies while reducing waste generation. Recognizing this potential, developers of $\mathrm{C}-\mathrm{H}$ functionalization methodologies often include in their reports examples of commercially available complex substrates such as sclareolide (1) or artemisinin (2) (Figure 1). While wisdom gained from this practice has contributed to many successful applications of C$\mathrm{H}$ functionalization in total synthesis, ${ }^{2}$ a complementary approach involving comparison of varied methodologies on a single complex scaffold would greatly improve understanding of the fate of complex molecules under conditions for $\mathrm{C}-\mathrm{H}$ functionalization. Furthermore, the direct comparison of various protocols for the same transformation on a single substrate would be a good indicator of how practical a method might be in the synthesis of a complex molecule.

The concept of diversifying complex scaffolds using $\mathrm{C}-\mathrm{H}$ functionalization has gained traction within the past decade, ${ }^{3}$ with various research groups communicating derivatizations of molecules as diverse as drug candidates, ${ }^{4}$ organic light-emitting diodes (OLEDs), ${ }^{5}$ metal-organic frameworks (MOFs), ${ }^{6}$ and polymers, ${ }^{7}$ most commonly by way of $\mathrm{C}\left({ }_{s p} 2\right)-\mathrm{H}$ functionalization. However, few reports exist detailing comparative studies of methodologies for $\mathrm{C}\left({ }_{\mathrm{sp}} 3\right)-\mathrm{H}$ oxidation on a single complex

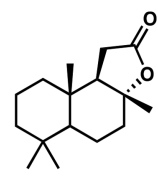

Sclareolide (1)

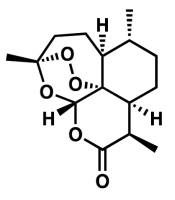

Artemisinin (2)

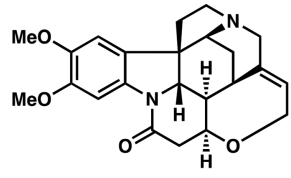

Brucine (3)

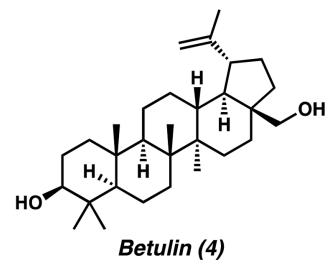

Betulin (4)
Figure 1. Commercially available complex molecules employed in previous $\mathrm{C}-\mathrm{H}$ functionalization studies.

scaffold. An account by Davies and Beckwith explores assorted conditions and catalysts for $\mathrm{C}-\mathrm{C}$ bond formation on the complex alkaloid brucine $(3)^{8}$ while a report by Malik and coworkers compares the efficacies of various $\mathrm{C}-\mathrm{O}$ bond-forming methods on relatively simple substrates. ${ }^{9}$ Nevertheless, so far the only comparative study involving $\mathrm{C}-\mathrm{O}$ bond formation on a complex scaffold was disclosed by Baran and co-workers in $2014,{ }^{10}$ describing the oxidation of betulin (4) in conjunction

Received: December 29, 2017

Published: January 9, 2018 
with the optimization of physicochemical properties relevant to drug discovery. ${ }^{11,12}$

We envisioned that the tricyclic carbon framework (6) of the cyanthiwigin natural product family could serve as a complex scaffold on which to conduct a comparative study of $\mathrm{C}-\mathrm{H}$ oxidation methodologies. As was recently pointed out by Miller et al., ${ }^{13}$ broad availability of natural product scaffolds is often limiting. Our study employs a fully synthetic, but readily available, scaffold (6) based on a highly efficient seven-step sequence from succinic acid (5) previously described by our group. ${ }^{14}$ Diketone 6 features an $\mathrm{A}-\mathrm{B}-\mathrm{C}$ tricyclic fused carbon skeleton containing a variety of $\mathrm{C}-\mathrm{H}$ bonds. Additionally, the presence of two quaternary stereocenters allows for assessment of steric influences, while the two carbonyl moieties enable examination of electronic factors on product selectivity (Figure 2). Elucidating the behavior of tricycle 6 under diverse

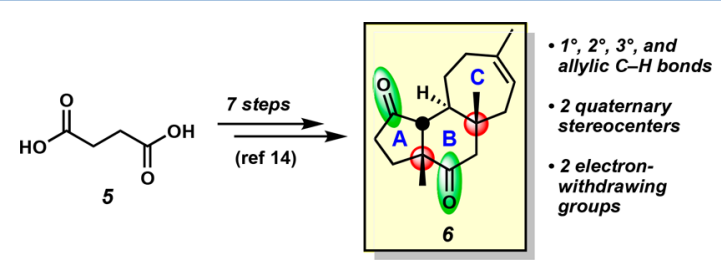

Figure 2. Availability of the cyanthiwigin core (6) from succinic acid (5) and features relevant to reactivity under common conditions for $\mathrm{C}-\mathrm{H}$ oxidation.

conditions for $\mathrm{C}-\mathrm{H}$ oxidation would provide insights into the reactivity of complex molecules complementary to previous findings on commercially available scaffolds.

This report is not intended as an exhaustive survey of all known strategies for $\mathrm{C}-\mathrm{H}$ oxidation but rather as a sampling of a balanced cross-section of the literature. Due to the importance of selective heteroatom incorporation in chemical synthesis, we have chosen to focus our efforts on $\mathrm{C}-\mathrm{H}$ oxidation with further specialization on intermolecular strategies, which do not require the installation and removal of directing functionalities as most intramolecular methods do. ${ }^{15}$ To the best of our knowledge, this is the first report of comparative $\mathrm{C}-\mathrm{H}$ oxidation studies including $\mathrm{C}-\mathrm{O}, \mathrm{C}-\mathrm{N}$, and $\mathrm{C}-\mathrm{X}$ bond formation on a complex synthetic molecular scaffold. Distinct from the multitude of studies that employ a single method on a variety of substrates, this contribution discloses a rare example of a single natural product scaffold serving as an exploratory substrate for diverse methods for C$\mathrm{H}$ functionalization.

\section{RESULTS AND DISCUSSION}

C-O Bond Formation. Allylic $\mathrm{C}-\mathrm{H}$ Acetoxylation. We began our studies with oxidation of the most activated $\mathrm{C}-\mathrm{H}$ bonds in the cyanthiwigin framework, those at allylic positions. Treatment of 6 with stoichiometric quantities of selenium dioxide in refluxing ethanol ${ }^{16}$ afforded enal 7 in moderate yield (42\%) along with allylic alcohol 8 (22\%) (Table 1, entry 1$)$. In contrast, the use of catalytic selenium with stoichiometric tertbutyl hydroperoxide (TBHP) at room temperature ${ }^{17}$ enabled formation of $\mathbf{8}$ as the major product, with only trace amounts of enal 7 observed in the crude reaction mixture (entry 2). Interestingly, in both of these experiments, oxidation was observed only at the $\mathrm{C} 15$ methyl group despite evidence suggesting the endocyclic C11 position would be favored. ${ }^{18}$
Table 1. Allylic Oxidation of Tricycle 6 by $\mathrm{SeO}_{2}$

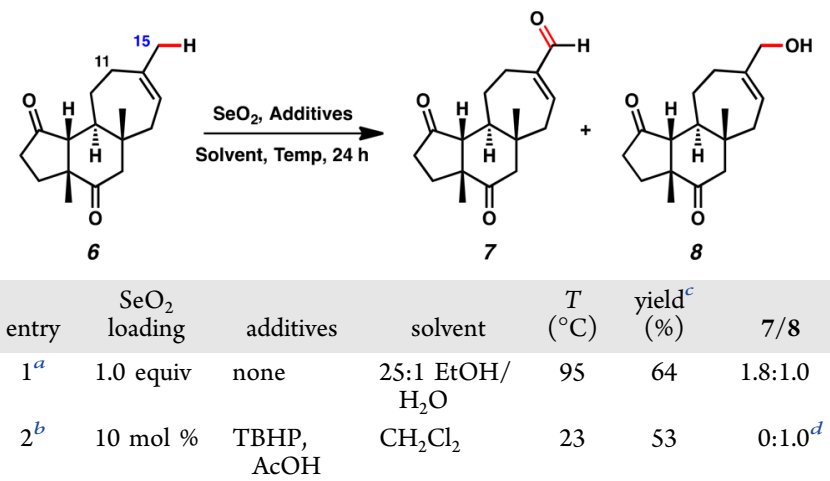

${ }^{a}$ Conditions adapted from ref $16 .{ }^{b}$ Conditions adapted from ref 17. ${ }^{c}$ Combined isolated yields of 7 and $8 .{ }^{d}$ Trace amount of enal 7 was observed in the crude reaction mixture.

Shifting our attention to more recently developed procedures for allylic oxidation, we investigated the effectiveness of different strategies employing Pd catalysis (Table 2). Efforts to effect allylic $\mathrm{C}-\mathrm{H}$ acetoxylation using catalytic $\mathrm{Pd}(\mathrm{OAc})_{2}$ with either $\mathrm{O}_{2}$ or $p$-benzoquinone (BQ) as the oxidant, conditions reported previously by $\mathrm{Stahl}^{19}$ and White, ${ }^{20}$ respectively, resulted in little to no conversion of tricycle 6 (entries 1 and 2). Employing $\mathrm{Pd}^{\mathrm{II}}$ complex 10 as the catalyst and changing the solvent system provided similar results (entry 3). Likewise, a protocol developed previously by our group for allylic acetoxylation using Oxone as the terminal oxidant ${ }^{21}$ proved ineffective for the oxidation of 6 (entry 4). Interestingly, however, modification of the conditions including increased reaction temperature resulted in the formation of $\mathrm{C} 15$ acetoxylation product 9 in modest yield (entry 5). Notably, no oxidation was observed at the $\mathrm{C} 11$ and $\mathrm{C} 14$ positions, possibly due to steric factors. ${ }^{22,23}$

Hydrogenation of the Cyanthiwigin Core. While the alkene functional group enabled exploration of allylic oxidation tactics, it proved to be a liability in the investigation of methods for C$\mathrm{H}$ hydroxylation, ${ }^{24}$ an important strategy in the modulation of physicochemical properties of lead candidates in drug discovery. ${ }^{10}$ To render the cyanthiwigin framework compatible with common $\mathrm{C}-\mathrm{H}$ hydroxylation conditions, the $\mathrm{C}$-ring olefin was removed through hydrogenation (Table 3). After unsuccessful attempts using catalytic (entry 1) or superstoichiometric $\mathrm{Pd} / \mathrm{C}$ in various solvent systems (entries 2-5), we were delighted to find that $\mathrm{PtO}_{2}$ catalyzed the transformation smoothly with $100 \%$ conversion of 6 (entry 6).

When hydrogenation was carried out at ambient temperature, saturated tricycle 11 was obtained in 6:1 dr, whereas when the temperature was lowered to $0{ }^{\circ} \mathrm{C}$, the $\mathrm{dr}$ increased to 9:1 (Scheme 1). ${ }^{25}$ To facilitate structural determination of the major diastereomer, deuterium-labeled compound 12 was prepared, permitting stereochemical elucidation by NOE analysis. This assignment was further substantiated by an $\mathrm{X}$ ray crystal structure of compound $\mathbf{1 1}$. The stereoselectivity of the reaction likely arises from steric constraints, with hydrogenation occurring preferentially on the more accessible $\alpha$-face of 6.

C-O Bond Formation. Tertiary $\mathrm{C}-\mathrm{H}$ Hydroxylation. With saturated tricycle $\mathbf{1 1}$ in hand, we proceeded to conduct a comparative study of $3^{\circ} \mathrm{C}-\mathrm{H}$ bond hydroxylation protocols (Table 4). Initial investigations using catalytic $\mathrm{RuCl}_{3} \cdot x \mathrm{H}_{2} \mathrm{O}$ supplied tertiary alcohol $\mathbf{1 3}$ in moderate yield (entry 1), ${ }^{26}$ and 
Table 2. Pd-Catalyzed Allylic Acetoxylation of Tricycle 6

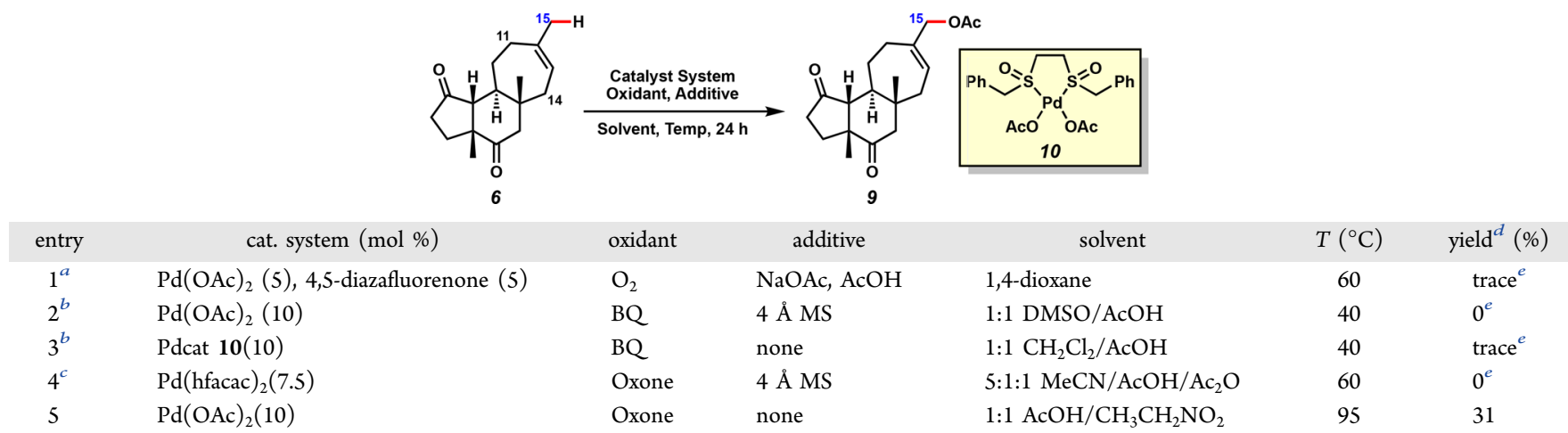

${ }^{a}$ Conditions adapted from ref $19 .{ }^{b}$ Conditions adapted from ref $20 .{ }^{c}$ Conditions adapted from ref $21 .{ }^{d}$ Isolated yield. ${ }^{e}$ Starting material was recovered $(>90 \%)$.

Table 3. Hydrogenation of Tricycle 6

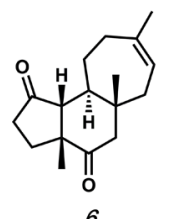

$$
6
$$

entry catalyst

Pd/C $\quad 3$ mol \%

$\mathrm{Pd} / \mathrm{C} \quad 2.3$ equiv

$\mathrm{Pd} / \mathrm{C} \quad 3.5$ equiv

$\mathrm{Pd} / \mathrm{C} \quad 3.0$ equiv

$\mathrm{Pd} / \mathrm{C} \quad 3.0$ equiv

$\mathrm{PtO}_{2} \quad 20 \mathrm{~mol} \%$

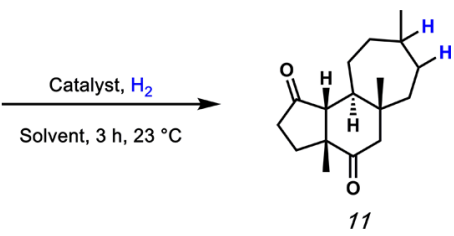

EtOAc

EtOAc

AcOH/EtOAc (2:1)

AcOH/EtOAc (5:2)

TFA/EtOAc(3:1)

EtOAc

\section{conversion (\%)}

0

0
0

0

0

0

100
Scheme 1. Stereoselectivity in Hydrogenation of Tricycle 6

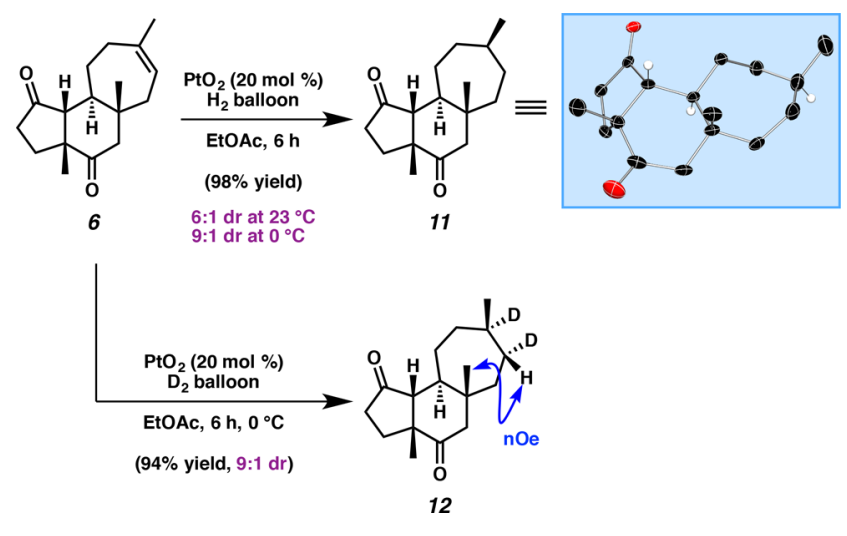

the milder $\left(\mathrm{Me}_{3} \mathrm{tacn}\right) \mathrm{RuCl}_{3}$ (tacn = 1,4,7-trimethyl-1,4,7triazacyclononane) system proved even more effective (entry 2). ${ }^{27}$ Application of metal-free conditions ${ }^{28}$ using oxaziridine catalyst 14 resulted in significantly lower yields of $\mathbf{1 3}$ due to low conversion and epimerization at the $\mathrm{C} 12$ position, presumably through ionization of the tertiary alcohol in situ (entry 3). Likewise, the use of excess dimethyldioxirane (DMDO) provided only small quantities of 13, returning primarily unreacted 11 (entry 4). ${ }^{29}$ Fe-catalyzed $^{30}$ and Mn-catalyzed protocols were similarly inefficient, although starting material was consumed in both cases, suggesting side reactivity as a significant detriment to product yield (entries 5 and 6). For instance, the formation of smaller quantities of a product suspected to arise from $\mathrm{C} 13$ oxidation was also observed.
Table 4. Tertiary C-H Hydroxylation of Tricycle 10
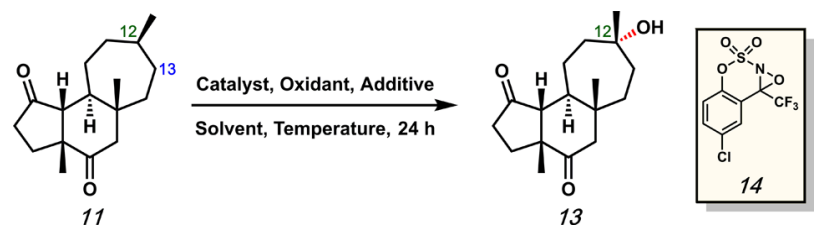

\begin{tabular}{|c|c|c|c|c|c|c|}
\hline entry & $\begin{array}{l}\text { catalyst } \\
(\mathrm{mol} \%)\end{array}$ & oxidant & additive & solvent & $\begin{array}{c}T \\
\left({ }^{\circ} \mathrm{C}\right)\end{array}$ & $\begin{array}{c}\text { yield }^{g} \\
(\%)\end{array}$ \\
\hline $1^{a}$ & $\underset{(5)}{\mathrm{RuCl}_{3}} \cdot x \mathrm{H}_{2} \mathrm{O}$ & $\mathrm{KBrO}_{3}$ & pyridine & $\begin{array}{c}\mathrm{MeCN} / \\
\mathrm{H}_{2} \mathrm{O}\end{array}$ & 60 & $42^{h, l}$ \\
\hline $2^{b}$ & $\begin{array}{l}\left(\mathrm{Me}_{3} \mathrm{tacn}\right) \\
\mathrm{RuCl}_{3}(2)\end{array}$ & CAN & $\mathrm{AgClO}_{4}$ & $\begin{array}{c}t-\mathrm{BuOH} / \\
\mathrm{H}_{2} \mathrm{O}\end{array}$ & 23 & $64^{h, l}$ \\
\hline $3^{c}$ & $\begin{array}{l}\text { oxaziridine } 14 \\
\quad(20)\end{array}$ & Oxone & none & $\begin{array}{l}\mathrm{HFIP} / \\
\mathrm{H}_{2} \mathrm{O}\end{array}$ & 70 & $21^{h, l}$ \\
\hline $4^{d}$ & none & DMDO & none & acetone & 23 & $15^{h}$ \\
\hline $5^{e}$ & $\begin{array}{l}\mathrm{Fe}(\mathrm{S}, \mathrm{S}-\mathrm{PDP}) \\
(15)^{i}\end{array}$ & $\mathrm{H}_{2} \mathrm{O}_{2}$ & $\mathrm{AcOH}$ & $\mathrm{MeCN}$ & 23 & $22^{j, m}$ \\
\hline $6^{f}$ & $\begin{array}{l}\mathrm{Mn}(\mathrm{OTf})_{2} \\
(0.1)\end{array}$ & $\mathrm{AcOOH}$ & bipy & $\begin{array}{c}\mathrm{AcOH} / \\
\mathrm{H}_{2} \mathrm{O}\end{array}$ & 23 & $20^{k, m}$ \\
\hline
\end{tabular}

${ }^{a}$ Conditions adapted from ref $26 .{ }^{b}$ Conditions adapted from ref 27. ${ }^{c}$ Conditions adapted from ref $28 .{ }^{d}$ Conditions adapted from ref $29 \mathrm{~b}$. ${ }^{e}$ Conditions adapted from ref $30 .{ }^{f}$ Conditions adapted from ref 9. ${ }^{g}$ Isolated yield. ${ }^{h}$ Starting material was recovered. ${ }^{i}$ Iterative protocol was employed $(3 \times 5 \mathrm{~mol} \%) .{ }^{j}$ Reaction time $=30 \mathrm{~min} .{ }^{k}$ Reaction time $=90 \mathrm{~s} .{ }^{l}$ Minor product with opposite stereochemistry at C12 was also observed. ${ }^{m}$ Ketone product 15 derived from $2^{\circ} \mathrm{C}-\mathrm{H}$ oxidation at C13 was also observed.

To elucidate the structure of the presumed $\mathrm{C} 13$ oxidation product, tricycle 11 was subjected to oxidation conditions in the presence of $\mathrm{Fe}\left(R, R-\mathrm{CF}_{3}-\mathrm{PDP}\right)$, a modified Fe-PDP catalyst known to prefer oxidation of $2^{\circ}$ over $3^{\circ} \mathrm{C}-\mathrm{H}$ bonds. ${ }^{31}$ Indeed, triketone 15 was formed as the major product, with a smaller amount of C12 oxidation product 13 also isolated (Scheme 2).

Scheme 2. Secondary C-H Oxidation of Tricycle $11^{a}$
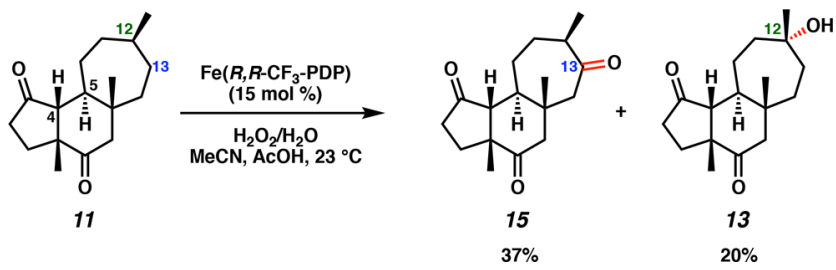

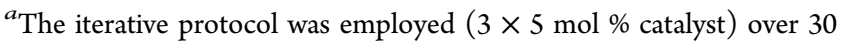
min; isolated yields conditions adapted from ref 31 . 
Table 5. Tertiary C-H Amination of Tricycle 11

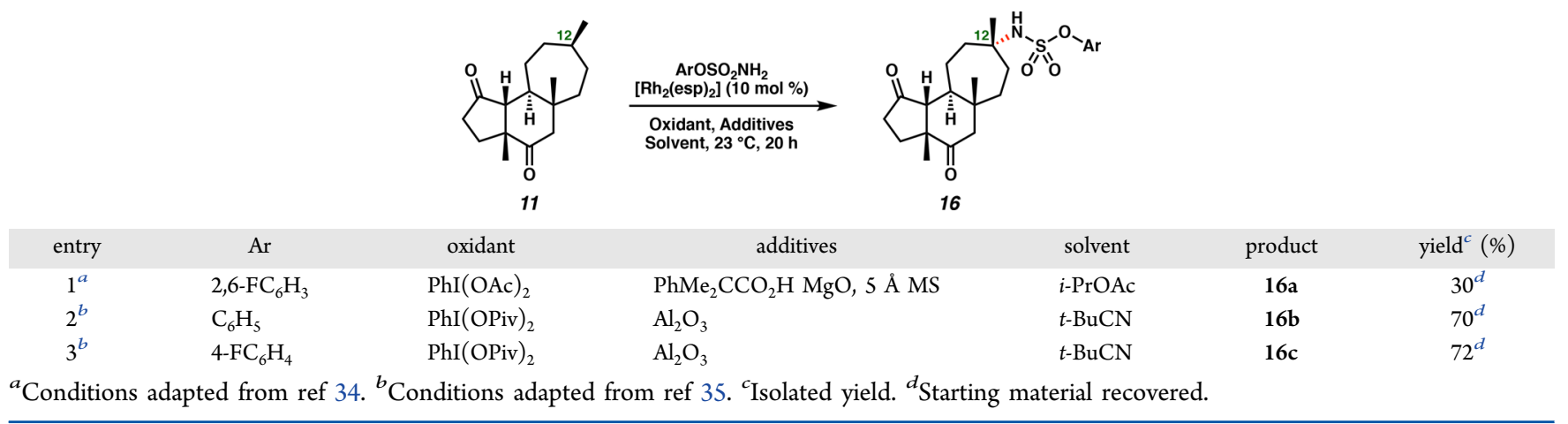

Comparison of the $1 \mathrm{H}$ NMR spectrum of triketone 15 with that of the side product from the Mn-catalyzed reaction (Table 4, entry 6) confirmed that $\mathrm{C} 13$ oxidation was in fact occurring. Throughout all of the $\mathrm{C}-\mathrm{H}$ hydroxylation experiments, oxidation was not observed at the $\mathrm{C} 4$ or $\mathrm{C} 5$ positions, likely due to deactivation by the nearby carbonyls and torsional strain associated with the axial configuration of those $\mathrm{C}-\mathrm{H}$ bonds. ${ }^{32}$ Although the yields and stereoselectivities of product formation in this system vary, it is interesting that all of the $\mathrm{C}-\mathrm{H}$ hydroxylation protocols display the same regioselectivity ( $\mathrm{C} 12$ oxidation), with one exception (cf. Scheme 2). In terms of synthetic design, this finding indicates that electronically remote $3^{\circ} \mathrm{C}-\mathrm{H}$ bonds are most likely to be oxidized and could provide enough confidence to the practitioner to incorporate this design feature into a complex synthetic plan.

$\mathrm{C}-\mathrm{N}$ Bond Formation. Tertiary $\mathrm{C}-\mathrm{H}$ Amination and Azidation. We next turned our attention to the formation of $\mathrm{C}-\mathrm{N}$ bonds, an important research area due to the ubiquity of nitrogen-containing bioactive molecules. ${ }^{33}$ Application of Du Bois's Rh-catalyzed methodology ${ }^{34}$ enabled formation of $\mathrm{C} 12$ amination product $\mathbf{1 6} \mathbf{a}$ in modest yield (Table 5, entry 1). Notably, challenges in product purification contributed substantially to the suboptimal isolated yields.

To address this, the Du Bois group has recently developed a revised protocol for intermolecular $\mathrm{C}-\mathrm{H}$ amination featuring fewer additives and simplified purification. ${ }^{35}$ Pleasingly, application of these conditions to tricycle $\mathbf{1 1}$ furnished $\mathrm{C}-\mathrm{H}$ amination product $16 \mathrm{~b}$ in greatly improved yield, with the remaining mass balance comprised of unreacted $\mathbf{1 1}$ (entry 2). Access to fluorine-containing product $16 \mathrm{c}$ was also achieved in good yield using the modified procedure (entry 3 ). In all cases, $\mathrm{C}-\mathrm{H}$ functionalization occurred selectively at $\mathrm{C} 12$ with retention of stereochemistry. As such, this new protocol for $\mathrm{C}-\mathrm{H}$ amination should prove particularly useful in late-stage, multistep synthesis.

Inspired by the success of the $\mathrm{C}-\mathrm{H}$ amination reactions, we continued our exploration of $\mathrm{C}-\mathrm{N}$ bond formation with $\mathrm{C}-\mathrm{H}$ azidation. Organic azides are readily reduced to primary amines and can be useful intermediates in the preparation of various nitrogen-containing compounds. ${ }^{36}$ A metal-free protocol reported by Tang and co-workers ${ }^{37}$ effected $\mathrm{C}-\mathrm{N}$ bond formation smoothly at the C12 position (Table 6, entry 1 ). Likewise, Hartwig's Fe-catalyzed conditions afforded comparably high conversion of 11 (entry 2). ${ }^{38}$ In both cases two products were isolated and characterized as diastereomers $17 \mathbf{a}$ and $\mathbf{1 7 b}$. The lack of stereoselectivity confirms observations from the methodological reports and indicates a loss of stereochemical information at the reactive site during the
Table 6. Tertiary C-H Azidation of Tricycle 11

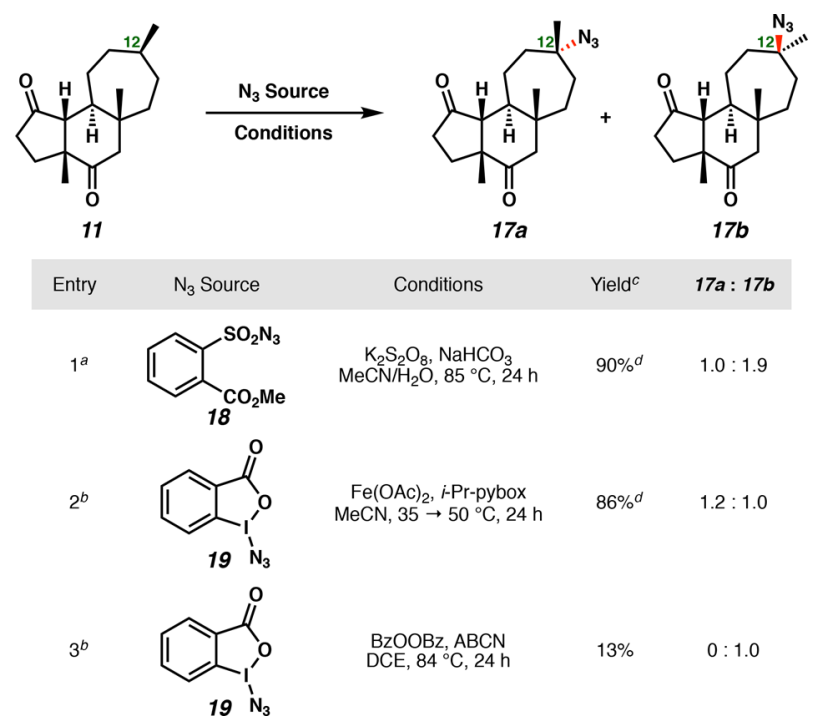

${ }^{a}$ Conditions adapted from ref $37 .{ }^{b}$ Conditions adapted from ref 38. ${ }^{c}$ Combined isolated yields of $17 \mathbf{a}$ and $17 \mathbf{b}$. ${ }^{d}$ Starting material recovered.

reaction mechanism, which likely proceeds through radical intermediates, as proposed by both Tang and Hartwig. Also in agreement with Hartwig's findings, efforts to initiate azidation using benzoyl peroxide resulted in poor yields and substrate decomposition (entry 3). ${ }^{39}$

C-X Bond Formation. Secondary $\mathrm{C}-\mathrm{H}$ Chlorination. To complete our studies, we examined $\mathrm{C}-\mathrm{H}$ halogenation of the cyanthiwigin core. Site-selective halogenation is an important aim in chemical synthesis due to the versatility of alkyl halides as synthetic building blocks. ${ }^{2 b}$ While efforts to fluorinate the cyanthiwigin scaffold proved challenging, ${ }^{40,41}$ a protocol for C$\mathrm{H}$ chlorination reported by Alexanian and Vanderwal offered modest success. ${ }^{42}$ Irradiation of tricycle 11 with visible light (23 W CFL) in the presence of $\mathrm{N}$-chloroamide 21 at $55^{\circ} \mathrm{C}$ resulted in chlorination of a $2^{\circ} \mathrm{C}-\mathrm{H}$ bond at the $\mathrm{C} 13$ position, generating chloride $\mathbf{2 0}$ in fair yield (Scheme 3). The remaining mass balance consisted of recovered starting material in addition to small quantities of unassigned dichlorinated products. $^{43}$

The regioselectivity observed in the chlorination reaction is likely influenced by both electronic and steric constraints. With the A- and B-rings deactivated by the electron-withdrawing carbonyl groups, the C-ring remains the most viable location for oxidation. As highlighted in Alexanian's original report, the 
Scheme 3. Secondary C-H Chlorination of Tricycle 10

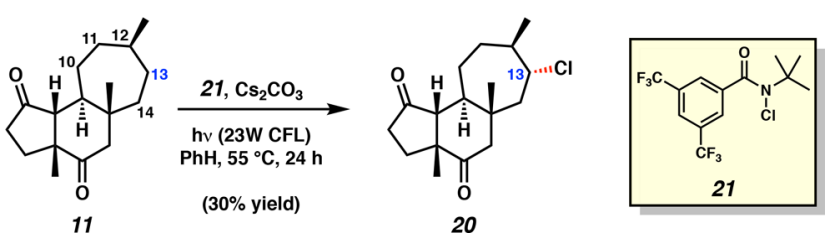

reaction is highly sensitive to steric environment due to the bulkiness of the chlorinating reagent, $\mathrm{N}$-chloroamide $\mathbf{2 1}$. Accordingly, chlorination occurs primarily at the $\mathrm{C} 13$ position, the least sterically encumbered site in the C-ring. Although the C11 position appears relatively unhindered as well, it is possible that anisotropic effects from the A-ring ketone cause electronic deactivation since the cupped conformation of the tricyclic system brings the A-ring carbonyl in proximity to the $\mathrm{C} 10$ and $\mathrm{C} 11$ positions on the $\mathrm{C}$-ring. Finally, the stereoselectivity of the C13 oxidation can also be explained by steric effects, as chlorination occurs preferentially on the less sterically burdened $\alpha$-face of 11, resembling the facial selectivity observed in the hydrogenation of $\mathbf{6}$ (cf. Scheme 1).

\section{CONCLUSION}

We have examined the reactivity of a complex natural product core in a comparative study of various known methods for C$\mathrm{H}$ oxidation. Having observed that selenium dioxide catalyzes the allylic oxidation of $\mathbf{6}$ more effectively than modern methods employing Pd catalysis, we conclude that the direct allylic $\mathrm{C}-\mathrm{H}$ acetoxylation of trisubstituted olefins in complex scaffolds remains a challenging transformation that could benefit from further methodological development. In the meantime, however, catalytic selenium dioxide offers a competent alternative for this important transformation.

Our investigations into tertiary $\mathrm{C}-\mathrm{H}$ oxidation showcase the efficacy of modern transition-metal catalysis in both $\mathrm{C}-\mathrm{H}$ hydroxylation and $\mathrm{C}-\mathrm{H}$ amination. The ability to moderate the reactivity of a highly oxidizing $\mathrm{Ru}$ species through judicious selection of ligand and reaction conditions enables access to complex $\mathrm{C}-\mathrm{H}$ hydroxylated products with high yields and stereoselectivities. Similarly, recent advances in Rh-catalyzed $\mathrm{C}-\mathrm{H}$ amination have significantly improved the synthetic viability of this valuable $\mathrm{C}-\mathrm{N}$ bond-forming strategy. In contrast to the high stereoselectivities observed in the $\mathrm{C}-\mathrm{H}$ hydroxylation and amination reactions, protocols for $3^{\circ} \mathrm{C}-\mathrm{H}$ azidation tend to permit epimerization at the site of oxidation, limiting applications in chemical synthesis despite overall high conversion. Finally, there remains room for growth in the area of $\mathrm{C}-\mathrm{Cl}$ bond formation by $\mathrm{C}-\mathrm{H}$ functionalization, although the ability to isolate a single enantiopure product in serviceable yield is an impressive feat and a convenient resource for the chlorination of organic compounds.

To conclude, the results of these studies indicate that electronic and steric factors play significant roles in determining the regio- and stereoselectivity in $\mathrm{C}-\mathrm{H}$ oxidation reactions of complex molecules, corroborating accounts by other research groups. Furthermore, the tendency for functionalization to occur at just one site $(\mathrm{C} 12)$ in the 17 -carbon hydrogenated cyanthiwigin core (11) under vastly differing conditions for C$\mathrm{H}$ oxidation lends credence to the concept of "innate" functionalizations guided by the intrinsic reactivities of $\mathrm{C}-\mathrm{H}$ bonds within the substrate. ${ }^{29,44}$ This finding also highlights the importance of developing catalyst systems that alter regiose- lectivity and enable functionalization of intrinsically less reactive $\mathrm{C}-\mathrm{H}$ bonds (e.g., $\mathrm{C} 13$-selective oxidation). We anticipate that this contribution will enhance the applicability of $\mathrm{C}-\mathrm{H}$ oxidation to the elaboration of complex scaffolds by providing a useful comparison point for synthetic chemists aiming to install heteroatom functionality in complex molecule synthesis via late-stage $\mathrm{C}-\mathrm{H}$ functionalization.

\section{EXPERIMENTAL SECTION}

General Methods. Unless noted in the specific procedure, reactions were performed in flame-dried glassware under argon atmosphere. Dried and deoxygenated solvents were prepared by passage through columns of activated aluminum before use. Methanol was distilled from magnesium methoxide immediately prior to use. 1,2dichloroethane and hexafluoroisopropanol were distilled from calcium hydride immediately prior to use. Isopropyl acetate was distilled and stored over activated molecular sieves ( $5 \AA$ ) immediately prior to use. Catalysts ( $\left.\mathrm{Me}_{3} \mathrm{tacn}\right) \mathrm{RuCl}_{3}$, 6-chloro-4-trifluoromethyl-1,2,3-benzoxathiazine-2,2-dioxide, $\mathrm{Mn}(\mathrm{OTf})_{2}$, and $\mathrm{Rh}_{2}(\mathrm{esp})_{2}$ were donated by the $\mathrm{Du}$ Bois group (Stanford) and used without further purification. The $\mathrm{Fe}(S, S$-PDP) catalyst was donated by the Sarpong group (UC Berkeley) and used without further purification. The $\mathrm{Fe}\left(R, R-\mathrm{CF}_{3}-\right.$ PDP) catalyst was donated by the White group (UIUC) and used without further purification. DMDO, ${ }^{45}$ 2,6-difluorophenyl sulfamate, ${ }^{34}$ sulfonyl azide $18,{ }^{46}$ hypervalent iodine reagent $19,{ }^{47}$ and $\mathrm{N}$ chloroamide $21^{42}$ were prepared according to known procedures. $p$ Benzoquinone was recrystallized from petroleum ether prior to use. Brine is defined as a saturated aqueous solution of sodium chloride. Reactions requiring external heat were modulated to the specified temperatures using an IKAmag temperature controller. Reaction progress was monitored by TLC or Agilent 1290 UHPLC-LCMS. TLC was performed using E. Merck silica gel 60 F254 precoated plates $(0.25 \mathrm{~mm})$ and visualized by UV fluorescence quenching, potassium permanganate, or $p$-anisaldehyde staining. SiliaFlash P60 academic silica gel (particle size $0.040-0.063 \mathrm{~mm}$ ) was used for flash chromatography. ${ }^{1} \mathrm{H}$ and ${ }^{13} \mathrm{C}$ NMR spectra were recorded on a Varian Inova 500 spectrometer (500 and $126 \mathrm{MHz}$, respectively), a Bruker AV III HD spectrometer equipped with a Prodigy liquid nitrogen temperature cryoprobe (400 and $101 \mathrm{MHz}$, respectively), or a Varian Mercury 300 spectrometer (300 and $75 \mathrm{MHz}$, respectively) and are reported in terms of chemical shift relative to residual $\mathrm{CHCl}_{3}(\delta 7.26$ and $\delta 77.16 \mathrm{ppm}$, respectively). Data for ${ }^{1} \mathrm{H}$ NMR spectra are reported as follows: chemical shift $(\delta \mathrm{ppm})$ (multiplicity, coupling constant $(\mathrm{Hz})$, integration). Abbreviations are used as follows: $\mathrm{s}=$ singlet, $\mathrm{bs}=$ broad singlet, $\mathrm{d}=$ doublet, $\mathrm{t}=$ triplet, $\mathrm{q}=$ quartet, $\mathrm{m}=$ complex multiplet. Infrared (IR) spectra were recorded on a PerkinElmer Paragon 1000 spectrometer using thin film samples on $\mathrm{KBr}$ plates, and are reported in frequency of absorption $\left(\mathrm{cm}^{-1}\right)$. High-resolution mass spectra (HRMS) were obtained from the Caltech Mass Spectral Facility using a JEOL JMS-600H high resolution mass spectrometer with fast atom bombardment $(\mathrm{FAB}+)$ ionization mode or were acquired using an Agilent 6200 Series TOF with an Agilent G1978A Multimode source in electrospray ionization (ESI+) mode. Optical rotations were measured with a JASCO P-1010 polarimeter at $589 \mathrm{~nm}$ using a $100 \mathrm{~mm}$ path-length cell.

Tricyclic Enal 7.

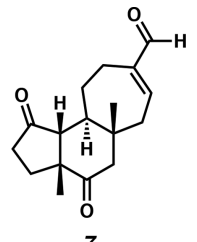

A solution of selenium dioxide $(5.5 \mathrm{mg}, 50 \mu \mathrm{mol}, 1.00$ equiv) in $25: 1$ ethanol/water $(1.0 \mathrm{~mL})$ was added dropwise to a solution of tricyclic diketone $6(13.0 \mathrm{mg}, 49.9 \mu \mathrm{mol}, 1.00$ equiv $)$ in absolute ethanol $(2.5 \mathrm{~mL})$, and the resulting mixture was heated to reflux (95 ${ }^{\circ} \mathrm{C}$ ) in an oil bath. After $24 \mathrm{~h}$, the reaction was allowed to cool to 23 
${ }^{\circ} \mathrm{C}$ and extracted with diethyl ether $(2 \times 5 \mathrm{~mL})$. The combined organic extracts were washed with water $(10 \mathrm{~mL})$ and dried over sodium sulfate. Filtration followed by concentration in vacuo afforded the crude residue, which was purified by silica gel column chromatography $(10 \% \rightarrow 20 \% \rightarrow 40 \% \rightarrow 60 \%$ ethyl acetate in hexanes), furnishing enal 7 as a colorless oil ( $5.7 \mathrm{mg}, 42 \%$ yield). $R_{f}=$ 0.25 (50\% ethyl acetate in hexanes); ${ }^{1} \mathrm{H}$ NMR $\left(\mathrm{CDCl}_{3}, 500 \mathrm{MHz}\right) \delta$ $9.39(\mathrm{~s}, 1 \mathrm{H}), 6.67$ (dddd, $J=8.8,5.0,2.5,1.4 \mathrm{~Hz}, 1 \mathrm{H}), 3.02$ (ddt, $J=$ $15.4,6.6,1.6 \mathrm{~Hz}, 1 \mathrm{H}), 2.78(\mathrm{~d}, J=14.5 \mathrm{~Hz}, 1 \mathrm{H}), 2.62-2.53(\mathrm{~m}, 2 \mathrm{H})$, $2.45-2.37(\mathrm{~m}, 1 \mathrm{H}), 2.36-2.30(\mathrm{~m}, 1 \mathrm{H}), 2.27(\mathrm{dd}, J=14.4,8.8 \mathrm{~Hz}$, $1 \mathrm{H}), 2.20$ (ddt, $J=15.4,6.6,1.6 \mathrm{~Hz}, 1 \mathrm{H}), 2.15(\mathrm{~d}, J=14.4 \mathrm{~Hz}, 1 \mathrm{H})$, $1.96-1.78(\mathrm{~m}, 4 \mathrm{H}), 1.12(\mathrm{~s}, 3 \mathrm{H}), 1.09-1.00(\mathrm{~m}, 1 \mathrm{H}), 0.76(\mathrm{~s}, 3 \mathrm{H})$; ${ }^{13} \mathrm{C} \mathrm{NMR}\left(\mathrm{CDCl}_{3}, 126 \mathrm{MHz}\right) \delta 217.1,211.6,193.0,150.9,148.2,62.7$, 52.4, 51.1, 47.5, 43.3, 40.4, 34.4, 31.5, 23.9, 22.5, 21.7, 17.6; IR (neat film, $\mathrm{KBr}$ ) 2927, 1732, 1704, 1682, 1456, 1384, 1262, 1178, 1155, 915, $732 \mathrm{~cm}^{-1}$; HRMS (EI+) $\mathrm{m} / z$ calcd for $\mathrm{C}_{17} \mathrm{H}_{22} \mathrm{O}_{3}\left[\mathrm{M}^{\bullet}\right]^{+}:$274.1569, found 274.1558; $[\alpha]^{25}{ }_{\mathrm{D}}-71.5\left(\right.$ c $\left.0.57, \mathrm{CHCl}_{3}\right)$.

Tricyclic Allylic Alcohol 8.

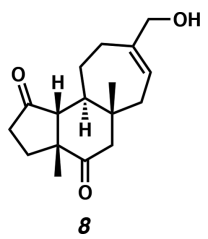

A round-bottom flask was charged with selenium dioxide $(0.3 \mathrm{mg}$, $2.5 \mu \mathrm{mol}, 0.10$ equiv), tert-butyl hydroperoxide (5.5 $\mathrm{M}$ solution in decane, $12 \mu \mathrm{L}, 6.3 \mu \mathrm{mol}, 2.50$ equiv), and acetic acid (1 drop), and the resulting mixture was diluted with dichloromethane $(0.50 \mathrm{~mL})$ and stirred at $23{ }^{\circ} \mathrm{C}$. After $30 \mathrm{~min}$, a solution of tricyclic diketone 6 (6.6 $\mathrm{mg}, 25.3 \mu \mathrm{mol}, 1.00$ equiv) in dichloromethane $(1.5 \mathrm{~mL})$ was added, and stirring was continued over the next $24 \mathrm{~h}$. After this time, the reaction mixture was filtered over Celite, and the filtrate was concentrated. The resulting residue was diluted with diethyl ether (5 $\mathrm{mL}$ ) and washed with $10 \%$ aq potassium hydroxide solution $(5 \mathrm{~mL})$, water $(5 \mathrm{~mL})$, and brine $(5 \mathrm{~mL})$. The organic layer was separated and dried over sodium sulfate before filtration and concentration. The crude residue was purified by silica gel column chromatography ( $10 \%$ $\rightarrow 20 \% \rightarrow 35 \% \rightarrow 40 \% \rightarrow 50 \%$ ethyl acetate in hexanes), affording allylic alcohol 8 as a colorless oil $(7.0 \mathrm{mg}, 53 \%$ yield $): R_{f}=0.16(50 \%$ ethyl acetate in hexanes $) ;{ }^{1} \mathrm{H}$ NMR $\left(\mathrm{CDCl}_{3}, 500 \mathrm{MHz}\right) \delta 5.61(\mathrm{t}, J=$ 6.7, 13.6, $1 \mathrm{H}), 4.04(\mathrm{~s}, 2 \mathrm{H}), 2.68(\mathrm{~d}, J=14.7 \mathrm{~Hz}, 1 \mathrm{H}), 2.59-2.51(\mathrm{~m}$, $1 \mathrm{H}), 2.42-2.30(\mathrm{~m}, 3 \mathrm{H}), 2.17-2.04(\mathrm{~m}, 3 \mathrm{H}), 2.06(\mathrm{~d}, J=14.7 \mathrm{~Hz}$, $1 \mathrm{H}), 1.92-1.82(\mathrm{~m}, 3 \mathrm{H}), 1.81-1.74(\mathrm{~m}, 1 \mathrm{H}), 1.17-1.11(\mathrm{~m}, 1 \mathrm{H})$, $1.11(\mathrm{~s}, 3 \mathrm{H}), 0.72(\mathrm{~s}, 3 \mathrm{H}) ;{ }^{13} \mathrm{C} \mathrm{NMR}\left(\mathrm{CDCl}_{3}, 101 \mathrm{MHz}\right) \delta 217.8$, 212.5, 145.4, 121.9, 67.5, 63.1, 52.5, 51.0, 47.8, 42.0, 40.0, 34.4, 31.4, 28.7, 24.6, 21.8, 17.3; IR (neat film, KBr) 3446 (br), 2925, 2853, 1733, 1704, 1456, 1384, 1178, 1149, 1024, $732 \mathrm{~cm}^{-1}$; HRMS (EI+) $\mathrm{m} / \mathrm{z}$ calcd for $\mathrm{C}_{17} \mathrm{H}_{24} \mathrm{O}_{3}\left[\mathrm{M}^{\bullet}\right]^{+}$276.1726, found 276.1716; $[\alpha]^{25}{ }_{\mathrm{D}}-68.0(c$ $0.31, \mathrm{CHCl}_{3}$ ).

Tricyclic Allylic Acetate 9.

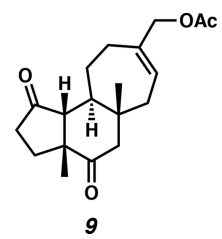

A flame-dried 1-dram vial was charged with tricyclic diketone 6 (10.0 mg, $38.1 \mu \mathrm{mol}, 1.00$ equiv), palladium(II) acetate (0.9 mg, 3.8 $\mu \mathrm{mol}, 0.10$ equiv), and Oxone (13 mg, $42 \mu \mathrm{mol}, 1.10$ equiv), and the resulting mixture was diluted with $1: 1 \mathrm{acetic}$ acid/nitroethane $(0.30$ $\mathrm{mL}$ total). The vial was sealed with a Teflon-lined cap and heated to $95^{\circ} \mathrm{C}$ using a heating block. After $24 \mathrm{~h}$, heating was discontinued, and the reaction mixture was quenched with aq sodium bicarbonate (1.0 $\mathrm{mL})$ and extracted with ethyl acetate $(3 \times 5 \mathrm{~mL})$. The combined organic extracts were dried over sodium sulfate, filtered, and concentrated. The resulting crude residue was purified by silica gel column chromatography $(10 \% \rightarrow 30 \%$ ethyl acetate in hexanes), delivering allylic acetate 9 as a colorless oil $\left(3.9 \mathrm{mg}, 31 \%\right.$ yield): $R_{f}=$ 0.14 (33\% ethyl acetate in hexanes); ${ }^{1} \mathrm{H}$ NMR $\left(\mathrm{CDCl}_{3}, 400 \mathrm{MHz}\right) \delta$ $5.66(\mathrm{dd}, J=8.8,5.3 \mathrm{~Hz}, 1 \mathrm{H}), 4.47(\mathrm{~s}, 2 \mathrm{H}), 2.68(\mathrm{~d}, J=14.6 \mathrm{~Hz}, 1 \mathrm{H})$, $2.58-2.50(\mathrm{~m}, 1 \mathrm{H}), 2.40-2.29(\mathrm{~m}, 3 \mathrm{H}), 2.16-2.12(\mathrm{~m}, 2 \mathrm{H}), 2.10-$ $2.05(\mathrm{~m}, 1 \mathrm{H}), 2.07(\mathrm{~s}, 3 \mathrm{H}), 2.04-2.01(\mathrm{~m}, 1 \mathrm{H}), 1.92-1.77(\mathrm{~m}, 4 \mathrm{H})$, $1.14-1.12(\mathrm{~m}, 1 \mathrm{H}), 1.11(\mathrm{~s}, 3 \mathrm{H}), 0.72(\mathrm{~s}, 3 \mathrm{H}) ;{ }^{13} \mathrm{C} \mathrm{NMR}\left(\mathrm{CDCl}_{3}\right.$, $101 \mathrm{MHz}) \delta 217.8,212.3,171.1,140.6,125.8,68.8,63.0,52.5,51.0$, 47.8, 42.0, 39.9, 34.4, 31.4, 28.8, 24.4, 21.8, 21.2, 17.3; IR (neat film, $\mathrm{KBr}) 2919,2850,1736,1703,1458,1384,1227,1025,959 \mathrm{~cm}^{-1}$; HRMS $(\mathrm{FAB}+) \mathrm{m} / z$ calcd for $\mathrm{C}_{19} \mathrm{H}_{26} \mathrm{O}_{4}\left[\mathrm{M}^{\bullet}\right]^{+}$318.1831, found 318.1823; $[\alpha]_{D}^{25}-58.2\left(c 0.25, \mathrm{CHCl}_{3}\right)$.

Hydrogenated Tricycle 11.

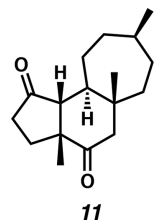

To a solution of tricyclic diketone $6(15.0 \mathrm{mg}, 57.6 \mu \mathrm{mol}, 1.00$ equiv) in ethyl acetate $(10 \mathrm{~mL})$ was added platinum dioxide $(2.6 \mathrm{mg}$, $11.4 \mu \mathrm{mol}, 0.20$ equiv), and the resulting suspension was cooled in an ice/water bath. A hydrogen balloon connected to a three-way adapter was fitted to the flask, and the headspace was evacuated for $3 \mathrm{~min}$ $(\sim 400$ Torr $)$ and backfilled with hydrogen gas. This process was repeated twice more, after which the reaction mixture was allowed to stir at $0{ }^{\circ} \mathrm{C}$ under hydrogen atmosphere. Within a few minutes, the color of the reaction mixture changed from brown to black. After $6 \mathrm{~h}$, the solvent was removed in vacuo, and the resulting residue was passed through a pad of silica gel, eluting with $20 \%$ ethyl acetate in hexanes $(150 \mathrm{~mL})$. Concentration of the filtrate afforded saturated tricycle 11 as a colorless oil that required no further purification (14.5 mg, $96 \%$ yield). Crystals for X-ray diffraction were grown using slow evaporation of trace amounts of dichloromethane and chloroform- $d_{3}$ at $-20{ }^{\circ} \mathrm{C}$ over a 5-month period: $R_{f}=0.43(25 \%$ ethyl acetate in hexanes); ${ }^{1} \mathrm{H} \mathrm{NMR}\left(\mathrm{CDCl}_{3}, 300 \mathrm{MHz}\right) \delta 2.59(\mathrm{~d}, J=15.2 \mathrm{~Hz}, 1 \mathrm{H})$, $2.55-2.44(\mathrm{~m}, 1 \mathrm{H}), 2.43-2.21(\mathrm{~m}, 2 \mathrm{H}), 2.05(\mathrm{~d}, J=14.8 \mathrm{~Hz}, 1 \mathrm{H})$, $1.90(\mathrm{~d}, J=12.6, \mathrm{~Hz}, 1 \mathrm{H}), 1.86-1.77(\mathrm{~m}, 2 \mathrm{H}), 1.76-1.69(\mathrm{~m}, 1 \mathrm{H})$, $1.68-1.60(1 \mathrm{H}), 1.55-1.48(\mathrm{~m}, 2 \mathrm{H}), 1.47-1.38(\mathrm{~m}, 3 \mathrm{H}), 1.36-1.27$ $(\mathrm{m}, 2 \mathrm{H}), 1.11(\mathrm{~s}, 3 \mathrm{H}), 0.89(\mathrm{~d}, J=6.8 \mathrm{~Hz}, 3 \mathrm{H}), 0.77(\mathrm{~s}, 3 \mathrm{H}) ;{ }^{13} \mathrm{C}$ NMR $\left(\mathrm{CDCl}_{3}, 101 \mathrm{MHz}\right) \delta 218.2,213.1,62.3,52.8,51.0,45.0,42.0$, 41.8, 34.4, 34.3, 31.5, 31.1, 29.3, 23.4, 21.8, 21.4, 19.1; IR (neat film, $\mathrm{KBr}) 2952,2919,1737,1705,1458,1384,1172,1124,1052 \mathrm{~cm}^{-1}$; HRMS $(\mathrm{FAB}+) \mathrm{m} / z$ calcd for $\mathrm{C}_{17} \mathrm{H}_{27} \mathrm{O}_{2}[\mathrm{M}+\mathrm{H}]^{+} 263.2011$, found 263.2020; $[\alpha]_{\mathrm{D}}^{25}-61.3\left(\right.$ c $\left.0.31, \mathrm{CHCl}_{3}\right)$.

\section{Deuterated Tricycle 12.}

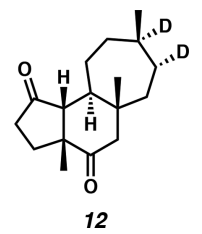

To a solution of tricyclic diketone $6(11.7 \mathrm{mg}, 44.9 \mu \mathrm{mol}, 1.00$ equiv) in ethyl acetate $(8.0 \mathrm{~mL})$ was added platinum dioxide $(2.1 \mathrm{mg}$, $9.2 \mu \mathrm{mol}, 0.20$ equiv), and the resulting suspension was cooled in an ice/water bath. A deuterium balloon connected to a three-way adapter was fitted to the flask, and the headspace was evacuated for $3 \mathrm{~min}$ ( $\sim 400$ Torr) and backfilled with deuterium gas. This process was repeated twice more, after which the reaction mixture was allowed to stir at $0{ }^{\circ} \mathrm{C}$ under deuterium atmosphere. Within a few minutes, the color of the reaction mixture changed from brown to black. After $6 \mathrm{~h}$, the solvent was removed in vacuo, and the resulting residue was passed through a pad of silica gel, eluting with $20 \%$ ethyl acetate in hexanes $(150 \mathrm{~mL})$. Concentration of the filtrate afforded deuterated tricycle 12 as a colorless oil which required no further purification $(11.2 \mathrm{mg}, 94 \%$ yield): $R_{f}=0.43$ (25\% ethyl acetate in hexanes); ${ }^{1} \mathrm{H}$ NMR $\left(\mathrm{CDCl}_{3}\right.$, $400 \mathrm{MHz}) \delta 2.59(\mathrm{~d}, J=14.8 \mathrm{~Hz}, 1 \mathrm{H}), 2.55-2.47(\mathrm{~m}, 1 \mathrm{H}), 2.40-2.31$ (m, $1 \mathrm{H}), 2.31-2.23(\mathrm{~m}, 1 \mathrm{H}), 2.04(\mathrm{~d}, J=14.7 \mathrm{~Hz}, 1 \mathrm{H}), 1.89(\mathrm{~d}, J=$ $12.5 \mathrm{~Hz} 1 \mathrm{H}), 1.87-1.80(\mathrm{~m}, 1 \mathrm{H}), 1.77-1.71(\mathrm{~m}, 1 \mathrm{H}), 1.64(\mathrm{~m}, 1 \mathrm{H})$, 
$1.56-1.51(\mathrm{~m}, 1 \mathrm{H}), 1.43-1.36(\mathrm{~m}, 3 \mathrm{H}), 1.32-1.28(\mathrm{~m}, 1 \mathrm{H}), 1.29-$ $1.26(\mathrm{~m}, 1 \mathrm{H}), 1.10(\mathrm{~s}, 3 \mathrm{H}), 0.90-0.85(\mathrm{~m}, 3 \mathrm{H}), 0.77(\mathrm{~s}, 3 \mathrm{H}) ;{ }^{13} \mathrm{C}$ NMR $\left(\mathrm{CDCl}_{3}, 101 \mathrm{MHz}\right) \delta 218.2,213.1,62.3,52.8,51.0,45.0,41.9$, 41.8, 34.3, 34.2, 31.1, 29.9, $28.8(\mathrm{t}, J=18.2,36.5 \mathrm{~Hz}), 23.3,21.8,21.4$, 19.0; IR (neat film, KBr) 2953, 2924, 1736, 1702, 1458, 1384, 1173, $1144,1052,804 \mathrm{~cm}^{-1}$; HRMS $(\mathrm{FAB}+) \mathrm{m} / z$ calcd for $\mathrm{C}_{17} \mathrm{H}_{24} \mathrm{O}_{2}{ }^{2} \mathrm{H}_{2}$ $\left[\mathrm{M}^{\bullet}\right]^{+}$264.2058, found 264.2047; $[\alpha]^{25}-77.7$ (c 1.12, $\mathrm{CHCl}_{3}$ ).

\section{Tertiary Alcohol 13.}

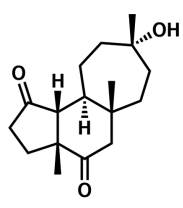

13

$\mathrm{C}-\mathrm{H}$ hydroxylation catalyzed by $\mathrm{RuCl}_{3} \cdot \mathrm{xH}_{2} \mathrm{O}$. A 1 -dram vial was charged with ruthenium(III) trichloride hydrate $(1.0 \mathrm{mg}, 0.95 \mu \mathrm{mol}$, 0.05 equiv) and potassium bromate $(9.6 \mathrm{mg}, 57.3 \mu \mathrm{mol}, 3.00$ equiv), and water $(0.2 \mathrm{~mL})$ and pyridine $(0.20 \mu \mathrm{L}, 1.91 \mu \mathrm{mol}, 0.10$ equiv $)$ were added sequentially. A solution of tricyclic diketone $11(5.0 \mathrm{mg}$, $19.1 \mu \mathrm{mol}, 1.00$ equiv in acetonitrile $(0.2 \mathrm{~mL}))$ was added, and the vial was sealed with a Teflon-lined cap and heated to $60{ }^{\circ} \mathrm{C}$ in a heating block with vigorous stirring. After $24 \mathrm{~h}$, heating was discontinued, and the reaction mixture was quenched with saturated aq sodium sulfite solution $(1.0 \mathrm{~mL})$, diluted with water $(1.0 \mathrm{~mL})$, and extracted with ethyl acetate $(3 \times 5 \mathrm{~mL})$. The combined organics were dried over sodium sulfate, filtered, and concentrated. The crude residue was purified by silica gel column chromatography $(10 \% \rightarrow 40 \% \rightarrow 50 \%$ ethyl acetate in hexanes), furnishing tertiary alcohol 13 as a white amorphous solid ( $2.2 \mathrm{mg}, 42 \%$ yield): $R_{f}=0.15$ (50\% ethyl acetate in hexanes); ${ }^{1} \mathrm{H} \mathrm{NMR}\left(\mathrm{CDCl}_{3}, 400 \mathrm{MHz}\right) \delta 2.63(\mathrm{~d}, J=15.0 \mathrm{~Hz}, 1 \mathrm{H})$, $2.59-2.45(\mathrm{~m}, 1 \mathrm{H}), 2.42-2.32(\mathrm{~m}, 1 \mathrm{H}), 2.26(\mathrm{dt}, J=13.3,10.3 \mathrm{~Hz}$, $1 \mathrm{H}), 2.08(\mathrm{~d}, J=15.1 \mathrm{~Hz}, 1 \mathrm{H}), 1.96-1.85(\mathrm{~m}, 3 \mathrm{H}), 1.80-1.71(\mathrm{~m}$, $3 \mathrm{H}), 1.71-1.63(\mathrm{~m}, 2 \mathrm{H}), 1.53(\mathrm{~s}, 1 \mathrm{H}), 1.24(\mathrm{~s}, 3 \mathrm{H}), 1.13(\mathrm{~s}, 3 \mathrm{H})$, $1.11-1.04(\mathrm{~m}, 1 \mathrm{H}), 0.75(\mathrm{~s}, 3 \mathrm{H}) ;{ }^{13} \mathrm{C}$ NMR $\left(\mathrm{CDCl}_{3}, 101 \mathrm{MHz}\right) \delta$ 218.2, 212.6, 73.8, 61.5, 52.7, 51.0, 46.9, 42.9, 40.9, 37.1, 36.2, 34.3, 31.2, 31.0, 21.8, 21.2, 19.0; IR (neat film, KBr) 3417 (br), 2958, 2925, 2853, 1738, 1704, 1463, 1384, 1261, 1126, 1052, $803 \mathrm{~cm}^{-1}$; HRMS (EI +) $\mathrm{m} / \mathrm{z}$ calcd for $\mathrm{C}_{17} \mathrm{H}_{24} \mathrm{O}_{2}\left[\mathrm{M}-\mathrm{H}_{2} \mathrm{O}\right] 260.1776$, found 260.1769; $[\alpha]_{\mathrm{D}}^{25}-9.5\left(\right.$ c $\left.0.28, \mathrm{CHCl}_{3}\right)$.

$\mathrm{C}-\mathrm{H}$ Hydroxylation Catalyzed by ( $\left.\mathrm{Me}_{3} \mathrm{tacn}\right) \mathrm{RuCl}_{3}$. A 1-dram vial was charged with (1,4,7-trimethyl-1,4,7-triazacyclononane)ruthenium(III) trichloride $(0.2 \mathrm{mg}, 0.63 \mu \mathrm{mol}, 0.020$ equiv), silver perchlorate ( $0.5 \mathrm{mg}, 2.50 \mu \mathrm{mol}, 0.080$ equiv), and water $(0.5 \mathrm{~mL})$. The vial was sealed with a Teflon-lined cap and heated to $80{ }^{\circ} \mathrm{C}$ in a heating block with vigorous stirring for $5 \mathrm{~min}$. The reaction mixture was then allowed to cool to $23{ }^{\circ} \mathrm{C}$, and a solution of saturated tricycle 11 (8.2 $\mathrm{mg}, 31.2 \mu \mathrm{mol}, 1.00$ equiv) in tert-butyl alcohol $(0.50 \mathrm{~mL})$ was added, followed by ceric(IV) ammonium nitrate $(51.4 \mathrm{mg}, 93.7 \mu \mathrm{mol}, 3.00$ equiv). The resulting mixture was stirred at $23{ }^{\circ} \mathrm{C}$ for $25 \mathrm{~min}$, at which time a second portion of ceric(IV) ammonium nitrate $(51.4 \mathrm{mg}, 93.7$ $\mu \mathrm{mol}, 3.00$ equiv) was added. After $24 \mathrm{~h}$, the reaction was quenched with methanol $(2 \mathrm{~mL})$, diluted with water $(5 \mathrm{~mL})$, and extracted with ethyl acetate $(3 \times 5 \mathrm{~mL})$. The combined organic extracts were dried over magnesium sulfate, filtered, and concentrated. The crude residue was purified by silica gel column chromatography $(10 \% \rightarrow 40 \% \rightarrow$ $50 \%$ ethyl acetate in hexanes), furnishing tertiary alcohol 13 as a white amorphous solid $(5.6 \mathrm{mg}, 64 \%$ yield) that matched the characterization data reported above.

$\mathrm{C}-\mathrm{H}$ Hydroxylation Catalyzed by Benzoxaziridine 14. A 1-dram vial was charged with saturated tricycle $11(10.0 \mathrm{mg}, 38.1 \mu \mathrm{mol}, 1.00$ equiv), 6-chloro-4-trifluoromethyl-1,2,3-benzoxathiazine-2,2-dioxide $\left(2.2 \mathrm{mg}, 7.62 \mu \mathrm{mol}, 0.20\right.$ equiv), ${ }^{48}$ and Oxone $(29.3 \mathrm{mg}, 95.3 \mu \mathrm{mol}$, 2.50 equiv), and this mixture was diluted with 9:1 water/ hexafluoroisopropanol ( $1.0 \mathrm{~mL}$ total volume). The vial was sealed with a Teflon-lined cap and heated to $70{ }^{\circ} \mathrm{C}$ in a heating mantle with vigorous stirring, forming the active catalyst 14 in situ. After $24 \mathrm{~h}$, the reaction was allowed to cool to $23{ }^{\circ} \mathrm{C}$, diluted with water $(5 \mathrm{~mL})$, and extracted with ethyl acetate $(3 \times 5 \mathrm{~mL})$. The combined organic extracts were dried over sodium sulfate, filtered, and concentrated. The crude residue was purified by silica gel column chromatography (10\% $\rightarrow 20 \% \rightarrow 50 \% \rightarrow 80 \%$ ethyl acetate in hexanes), affording tertiary alcohol 13 as a white amorphous solid (2.2 $\mathrm{mg}, 21 \%$ yield) that matched the characterization data reported above.

$\mathrm{C}-\mathrm{H}$ Hydroxylation Mediated by DMDO. A solution of dimethyldioxirane in acetone $(0.0125 \mathrm{M}, 24.4 \mathrm{~mL}, 0.305 \mathrm{mmol}, 8.00$ equiv) was added slowly to a solution of saturated tricycle 11 (10.0 $\mathrm{mg}, 38.1 \mu \mathrm{mol}, 1.00$ equiv) in acetone at $0{ }^{\circ} \mathrm{C}$. The resulting mixture was stirred at this temperature for $6 \mathrm{~h}$ before being allowed to gradually warm to $23{ }^{\circ} \mathrm{C}$ over $2 \mathrm{~h}$. After $16 \mathrm{~h}$ at this temperature, the volatiles were removed under reduced pressure, and the crude residue was purified by silica gel column chromatography $(10 \% \rightarrow 20 \% \rightarrow$ $50 \% \rightarrow 80 \%$ ethyl acetate in hexanes), affording tertiary alcohol 13 as a white amorphous solid (1.6 mg, $15 \%$ yield) that matched the characterization data reported above.

$\mathrm{C}-\mathrm{H}$ Hydroxylation Catalyzed by $\mathrm{Fe}(\mathrm{S}, \mathrm{S}-\mathrm{PDP})$. To a solution of tricyclic diketone $11(10.0 \mathrm{mg}, 38.1 \mu \mathrm{mol}, 1.00$ equiv) and $\mathrm{Fe}(S, S$ PDP) $(1.8 \mathrm{mg}, 1.91 \mu \mathrm{mol}, 0.050$ equiv) in acetonitrile $(1.0 \mathrm{~mL})$ was added acetic acid (1 drop). In a separate vial, a solution of hydrogen peroxide ( $50 \mathrm{wt} \%$ solution in water, $3.0 \mu \mathrm{L}, 45.7 \mu \mathrm{mol}, 1.20$ equiv) was diluted with acetonitrile $(0.30 \mathrm{~mL})$. This solution was added dropwise very slowly to the solution of $\mathbf{1 1}$ and $\mathrm{Fe}$ catalyst while stirring. After $10 \mathrm{~min}$ had elapsed, another solution of $\mathrm{Fe}$ (S,S-PDP) $(1.8 \mathrm{mg})$ in acetonitrile $(0.30 \mathrm{~mL})$ was added to the reaction mixture, followed by acetic acid ( 1 drop) and dropwise addition of another portion of hydrogen peroxide $(3.0 \mu \mathrm{L})$ in acetonitrile $(0.30 \mathrm{~mL})$. After $10 \mathrm{~min}$, this process was repeated once more. Ten minutes after the final addition (total reaction time of $30 \mathrm{~min}$ ), the volatiles were removed in vacuo, and the residue was diluted with diethyl ether (3 $\mathrm{mL}$ ) and filtered through a pad of silica gel. The filtrate was dried over magnesium sulfate, filtered, and concentrated in vacuo, and the crude residue was purified by silica gel column chromatography $(20 \% \rightarrow$ $40 \% \rightarrow 60 \% \rightarrow 80 \%$ ethyl acetate in hexanes) to furnish tertiary alcohol 13 as an amorphous white solid (2.3 $\mathrm{mg}, 22 \%$ yield) that matched the characterization data reported above.

$\mathrm{C}-\mathrm{H}$ Hydroxylation Catalyzed by $\mathrm{Mn}(\mathrm{OTf})_{2}$. Stock solutions were prepared as follows: manganese(II) triflate $(4.4 \mathrm{mg})$ was dissolved in 9:1 acetic acid/water $(1.0 \mathrm{~mL})$ to afford a $0.0125 \mathrm{M}$ solution. 2,2bipyridine $(3.9 \mathrm{mg})$ was dissolved in acetic acid $(1.0 \mathrm{~mL})$ to generate a $0.025 \mathrm{M}$ solution. Commercial peracetic acid was modified by adding $10 \%$ aq potassium hydroxide solution $(0.30 \mathrm{~mL})$ to a $35 \mathrm{wt} \%$ solution of peracetic acid in acetic acid $(1.0 \mathrm{~mL})$.

To a solution of tricyclic diketone $11(7.0 \mathrm{mg}, 26.7 \mu \mathrm{mol}, 1.00$ equiv) in acetic acid $(0.13 \mathrm{~mL})$ and water $(5.3 \mu \mathrm{L})$ were added sequentially solutions of manganese(II) triflate $(2.1 \mu \mathrm{L})$ and 2,2bipyridine $(10.7 \mu \mathrm{L})$. The resulting mixture was stirred for $10 \mathrm{~min}$, and then a solution of modified peracetic acid $(23.5 \mu \mathrm{L})$ was added very slowly in a dropwise fashion. After $90 \mathrm{~s}$, the reaction mixture was diluted with acetone $(2.7 \mathrm{~mL})$ and stirred for an additional $30 \mathrm{~s}$ before filtration through a small pad of Celite, rinsing with acetone $(5 \mathrm{~mL})$. The filtrate was concentrated under reduced pressure, and the resulting crude residue was purified by silica gel column chromatography $(10 \% \rightarrow 20 \% \rightarrow 50 \% \rightarrow 80 \%$ ethyl acetate in hexanes) to afford tertiary alcohol 13 as a white amorphous solid ( $1.5 \mathrm{mg}, 20 \%$ yield) that matched the characterization data reported above.

Tricyclic Triketone 15.

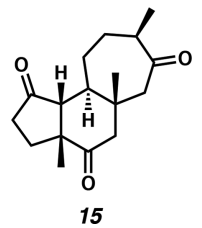

To a solution of tricyclic diketone $11(10.0 \mathrm{mg}, 38.1 \mu \mathrm{mol}, 1.00$ equiv) and $\mathrm{Fe}\left(R, R-\mathrm{CF}_{3}-\mathrm{PDP}\right)(2.6 \mathrm{mg}, 1.91 \mu \mathrm{mol}, 0.050$ equiv $)$ in acetonitrile $(1.0 \mathrm{~mL})$ was added acetic acid (1 drop). In a separate vial, a solution of hydrogen peroxide (50 wt \% solution in water, $3.0 \mu \mathrm{L}$, $45.7 \mu \mathrm{mol}, 1.20$ equiv) was diluted with acetonitrile $(0.30 \mathrm{~mL})$. This solution was added dropwise very slowly to the solution of $\mathbf{1 1}$ and Fe catalyst while stirring. After $10 \mathrm{~min}$ had elapsed, another solution of 
$\mathrm{Fe}\left(R, R-\mathrm{CF}_{3}-\mathrm{PDP}\right)(2.6 \mathrm{mg})$ in acetonitrile $(0.30 \mathrm{~mL})$ was added to the reaction mixture, followed by acetic acid (1 drop) and dropwise addition of another portion of hydrogen peroxide $(3.0 \mu \mathrm{L})$ in acetonitrile $(0.30 \mathrm{~mL})$. After $10 \mathrm{~min}$, this process was repeated once more. Ten minutes after the final addition (total reaction time of 30 $\mathrm{min}$ ), the volatiles were removed in vacuo, and the residue was diluted with ethyl acetate $(3 \mathrm{~mL})$ and filtered through a pad of silica gel. After concentration of the filtrate, the crude residue was purified by silica gel column chromatography $(20 \% \rightarrow 30 \% \rightarrow 50 \% \rightarrow 80 \%$ ethyl acetate in hexanes) to furnish ketone $\mathbf{1 5}$ as a colorless oil ( $3.9 \mathrm{mg}$, $37 \%$ yield): $R_{f}$ $=0.40$ (50\% ethyl acetate in hexanes); ${ }^{1} \mathrm{H}$ NMR $\left(\mathrm{CDCl}_{3}, 400 \mathrm{MHz}\right) \delta$ $2.70(\mathrm{~d}, J=14.2 \mathrm{~Hz}, 1 \mathrm{H}), 2.60-2.46(\mathrm{~m}, 4 \mathrm{H}), 2.44-2.36(\mathrm{~m}, 1 \mathrm{H})$, $2.27(\mathrm{~m}, 1 \mathrm{H}), 2.12(\mathrm{~d}, J=14.7 \mathrm{~Hz}, 1 \mathrm{H}), 2.04-1.97(\mathrm{~m}, 1 \mathrm{H}), 1.94(\mathrm{~m}$, $1 \mathrm{H}), 1.83-1.75(\mathrm{~m}, 2 \mathrm{H}), 1.62-1.58(\mathrm{~m}, 1 \mathrm{H}), 1.53-1.48(\mathrm{~m}, 1 \mathrm{H})$, $1.47-1.41(\mathrm{~m}, 1 \mathrm{H}), 1.15(\mathrm{~s}, 3 \mathrm{H}), 1.08(\mathrm{~d}, J=7.0 \mathrm{~Hz}, 3 \mathrm{H}), 0.87(\mathrm{~s}$, $3 \mathrm{H}) ;{ }^{13} \mathrm{C}$ NMR $\left(\mathrm{CDCl}_{3}, 101 \mathrm{MHz}\right) \delta 217.0,214.6,211.8,61.0,52.2$, 51.2, 47.2, 42.6, 41.4, 40.7, 39.3, 34.4, 31.2, 26.8, 21.9, 18.1, 18.1; IR (neat film, KBr) 2960, 2927, 1738 (overlapping peaks), 1704, 1456, 1384, 1261, 1172, 1108, $802 \mathrm{~cm}^{-1}$; HRMS (ESI+) $\mathrm{m} / z$ calcd for $\mathrm{C}_{17} \mathrm{H}_{25} \mathrm{O}_{3}[\mathrm{M}+\mathrm{H}]^{+}$277.1804, found 277.1819; $[\alpha]^{25}{ }_{\mathrm{D}}-6.9$ (c 0.39, $\left.\mathrm{CHCl}_{3}\right)$. Tertiary alcohol 13 was also isolated $(2.1 \mathrm{mg}, 20 \%$ yield), with characterization data matching the values reported above.

Sulfamate Ester 16a.

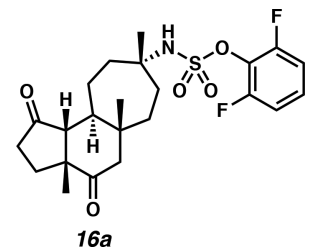

A 1-dram vial was charged with $5 \AA$ molecular sieves $(30 \mathrm{mg})$ and magnesium oxide $(2.9 \mathrm{mg}, 71.6 \mu \mathrm{mol}, 4.00$ equiv) and flame-dried under vacuum. Upon cooling, the reaction vessel was charged with 2,6difluorophenyl sulfamate ( $4.9 \mathrm{mg}, 23.3 \mu \mathrm{mol}, 1.30$ equiv), 2 phenylisobutyric acid $(1.5 \mathrm{mg}, 8.95 \mu \mathrm{mol}, 0.50$ equiv), and $\mathrm{Rh}_{2}(\mathrm{esp})_{2}(0.2 \mathrm{mg}, 0.18 \mu \mathrm{mol}, 0.010$ equiv), followed by a solution of tricyclic diketone 11 (4.7 mg, $17.9 \mu \mathrm{mol}, 1.00$ equiv) in isopropyl acetate $(1.0 \mathrm{~mL})$. The resulting green mixture was stirred for $5 \mathrm{~min}$ before the addition of (diacetoxyiodo)benzene $(11.5 \mathrm{mg}, 35.8 \mu \mathrm{mol}$, 2.00 equiv). The vial was then sealed with a Teflon-lined cap and stirred at $23{ }^{\circ} \mathrm{C}$. After $20 \mathrm{~h}$, the mixture was filtered through Celite and rinsed with ethyl acetate $(15 \mathrm{~mL})$. Concentration of the filtrate and purification of the crude residue by silica gel column chromatography ( $2 \%$ methanol in dichloromethane) afforded pure sulfamate ester 16a as a colorless oil $(2.5 \mathrm{mg}, 30 \%$ yield $): R_{f}=0.18$ (2\% methanol in dichloromethane); ${ }^{1} \mathrm{H}$ NMR $\left(\mathrm{CDCl}_{3}, 500 \mathrm{MHz}\right) \delta 7.21(\mathrm{td}, J=6.1$, $3.1 \mathrm{~Hz}, 1 \mathrm{H}), 7.02-6.99(\mathrm{~m}, 2 \mathrm{H}), 4.72(\mathrm{~s}, 1 \mathrm{H}), 2.64(\mathrm{~d}, J=15.1 \mathrm{~Hz}$, $1 \mathrm{H}), 2.58-2.48(\mathrm{~m}, 1 \mathrm{H}), 2.45-2.35(\mathrm{~m}, 1 \mathrm{H}), 2.31-2.25(\mathrm{~m}, 1 \mathrm{H})$, $2.20-2.13(\mathrm{~m}, 2 \mathrm{H}), 2.10(\mathrm{~d}, J=15.2 \mathrm{~Hz}, 1 \mathrm{H}), 2.03-1.98(\mathrm{~m}, 1 \mathrm{H})$, $1.91(\mathrm{~d}, J=12.8 \mathrm{~Hz}, 1 \mathrm{H}), 1.81-1.71(\mathrm{~m}, 5 \mathrm{H}), 1.50(\mathrm{~s}, 3 \mathrm{H}), 1.37-1.33$ $(\mathrm{m}, 1 \mathrm{H}), 1.15(\mathrm{~s}, 3 \mathrm{H}), 1.12(\mathrm{~m}, 1 \mathrm{H}), 0.78(\mathrm{~s}, 3 \mathrm{H}) ;{ }^{13} \mathrm{C} \mathrm{NMR}\left(\mathrm{CDCl}_{3}\right.$, $101 \mathrm{MHz}) \delta 218.1,212.3,156.2(\mathrm{dd}, J=253.2,4.0 \mathrm{~Hz}) 130.0(\mathrm{~d}, J=$ $29.5 \mathrm{~Hz}), 127.5(\mathrm{t}, J=18.5,9.1 \mathrm{~Hz}), 112.7(\mathrm{~m}), 62.1,61.1,52.4,51.0$, 46.9, 41.2, 40.7. 36.7, 34.3, 33.5, 31.0, 28.0, 21.8, 20.3, 19.0; ${ }^{19} \mathrm{~F}$ NMR $\left(\mathrm{CDCl}_{3}, 282 \mathrm{MHz}\right) \delta-124.0$; IR (neat film, $\left.\mathrm{KBr}\right) 3261$ (br), 2957, 2933, 1737, 1704, 1605, 1497, 1480, 1384, 1300, 1208, 1178, 1012, $861,745,734 \mathrm{~cm}^{-1}$; HRMS (ESI+) $\mathrm{m} / z$ calcd for $\mathrm{C}_{23} \mathrm{H}_{30} \mathrm{NO}_{5} \mathrm{~F}_{2} \mathrm{~S}[\mathrm{M}$ $+\mathrm{H}]^{+}$470.1813, found 470.1828; $[\alpha]^{25}-36.4$ (c 0.23, $\mathrm{CHCl}_{3}$ ).

Sulfamate Ester 16b.

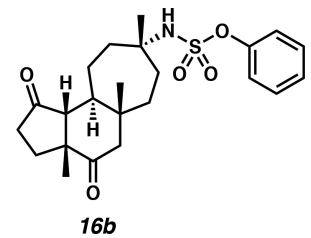

A 1-dram vial was charged with aluminum oxide $(15.5 \mathrm{mg}, 0.152$ mmol, 4.00 equiv, Brockmann grade 1, neutral) and flame-dried under vacuum. Upon cooling, the reaction vessel was charged with tricyclic diketone 11 ( $10.0 \mathrm{mg}, 38.1 \mu \mathrm{mol}, 1.00$ equiv), $\mathrm{Rh}_{2}(\mathrm{esp})_{2}(3.0 \mathrm{mg}, 3.81$ $\mu \mathrm{mol}, 0.10$ equiv), and phenyl sulfamate ( $8.6 \mathrm{mg}, 49.5 \mu \mathrm{mol}, 1.30$ equiv). The mixture was diluted with pivalonitrile $(1.0 \mathrm{~mL})$ and stirred at room temperature. After $5 \mathrm{~min}$, the green reaction mixture had turned navy blue, and di(pivaloyloxy)iodobenzene $(23.2 \mathrm{mg}, 57.2$ $\mu \mathrm{mol}, 1.5$ equiv) was added in a single portion. The reaction was stirred at $23{ }^{\circ} \mathrm{C}$ for $24 \mathrm{~h}$, developing a grayish hue during that time. The mixture was filtered through Celite and rinsed with ethyl acetate $(15 \mathrm{~mL})$. The filtrate was concentrated, and the crude residue was purified by column chromatography $(5 \% \rightarrow 15 \% \rightarrow 50 \%$ ethyl acetate in hexanes) to furnish pure sulfamate ester $\mathbf{1 6} \mathbf{b}$ as a colorless oil (11.6 $\mathrm{mg}, 70 \%$ yield): $R_{f}=0.22$ (33\% ethyl acetate in hexanes); ${ }^{1} \mathrm{H}$ NMR $\left(\mathrm{CDCl}_{3}, 400 \mathrm{MHz}\right) \delta 7.40-7.37(\mathrm{~m}, 2 \mathrm{H}), 7.30-7.27(\mathrm{~m}, 3 \mathrm{H}), 4.67(\mathrm{~s}$, $1 \mathrm{H}), 2.59(\mathrm{~d}, J=15.1 \mathrm{~Hz}, 1 \mathrm{H}), 2.54-2.45(\mathrm{~m}, 1 \mathrm{H}), 2.42-2.32(\mathrm{~m}$, $1 \mathrm{H}), 2.28-2.20(\mathrm{~m}, 1 \mathrm{H}), 2.11-2.04(\mathrm{~m}, 3 \mathrm{H}), 2.00-1.94(\mathrm{~m}, 1 \mathrm{H})$, $1.87(\mathrm{~d}, J=8.0 \mathrm{~Hz}, 1 \mathrm{H}), 1.79-1.75(\mathrm{~m}, 1 \mathrm{H}), 1.74-1.71(\mathrm{~m}, 1 \mathrm{H})$, $1.70-1.64(\mathrm{~m}, 4 \mathrm{H}), 1.45(\mathrm{~s}, 3 \mathrm{H}), 1.31-1.29(\mathrm{~m}, 1 \mathrm{H}), 1.13(\mathrm{~s}, 3 \mathrm{H})$, $0.75(\mathrm{~s}, 3 \mathrm{H}) ;{ }^{13} \mathrm{C}$ NMR $\left(\mathrm{CDCl}_{3}, 101 \mathrm{MHz}\right) \delta 218.1,212.2,150.4$, $129.9,126.9,121.8,61.4,61.1,52.5,51.0,47.0,41.4,40.7,36.7,34.3$, $33.7,31.0,28.3,21.8,20.3$, 18.9; IR (neat film, KBr) 3285 (br), 2958, 2927, 2254, 1736, 1702, 1588, 1488, 1459, 1376, 1194, 1171, 1150, $1054,913,859,782,731,691,647 \mathrm{~cm}^{-1}$; HRMS (FAB+) $\mathrm{m} / z$ calcd for $\mathrm{C}_{23} \mathrm{H}_{32} \mathrm{NO}_{5} \mathrm{~S}[\mathrm{M}+\mathrm{H}]^{+} 434.2001$, found 434.1999; $[\alpha]^{25}-33.5(c$ $1.16, \mathrm{CHCl}_{3}$ ).

Sulfamate Ester 16c.

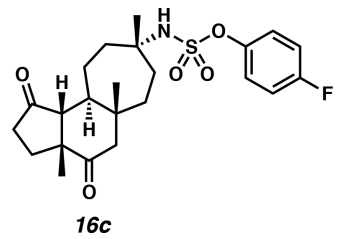

A 1-dram vial was charged with aluminum oxide $(15.5 \mathrm{mg}, 0.152$ mmol, 4.00 equiv, Brockmann grade 1 , neutral) and flame-dried under vacuum. Upon cooling, the reaction vessel was charged with tricyclic diketone 11 ( $10.0 \mathrm{mg}, 38.1 \mu \mathrm{mol}, 1.00$ equiv), $\mathrm{Rh}_{2}(\mathrm{esp})_{2}(3.0 \mathrm{mg}, 3.81$ $\mu \mathrm{mol}, 0.10$ equiv), and 4-fluorophenyl sulfamate $(9.5 \mathrm{mg}, 49.5 \mu \mathrm{mol}$, 1.30 equiv). The mixture was diluted with pivalonitrile $(1.0 \mathrm{~mL})$ and stirred at room temperature. After $5 \mathrm{~min}$, the green reaction mixture had turned navy blue, and di(pivaloyloxy)iodobenzene $(23.2 \mathrm{mg}, 57.2$ $\mu \mathrm{mol}, 1.50$ equiv) was added in a single portion. The reaction was stirred at $23{ }^{\circ} \mathrm{C}$ for $24 \mathrm{~h}$, developing a grayish hue during that time. The mixture was filtered through Celite and rinsed with ethyl acetate $(15 \mathrm{~mL})$. The filtrate was concentrated, and the crude residue was purified by column chromatography $(10 \% \rightarrow 20 \% \rightarrow 25 \%$ ethyl acetate in hexanes) to furnish pure sulfamate ester $16 \mathrm{c}$ as a colorless oil ( $12.4 \mathrm{mg}, 72 \%$ yield): $R_{f}=0.20$ (33\% ethyl acetate in hexanes); ${ }^{1} \mathrm{H}$ $\operatorname{NMR}\left(\mathrm{CDCl}_{3}, 500 \mathrm{MHz}\right) \delta 7.26-7.23(\mathrm{~m}, 2 \mathrm{H}), 7.10-7.05(\mathrm{~m}, 2 \mathrm{H})$, $4.59(\mathrm{~s}, 1 \mathrm{H}), 2.61(\mathrm{~d}, J=15.1 \mathrm{~Hz}, 1 \mathrm{H}), 2.55-2.47(\mathrm{~m}, 1 \mathrm{H}), 2.42-2.34$ $(\mathrm{m}, 1 \mathrm{H}), 2.29-2.22(\mathrm{~m}, 1 \mathrm{H}), 2.12-2.05(\mathrm{~m}, 2 \mathrm{H}), 2.09(\mathrm{~d}, J=14.7$ $\mathrm{Hz}, 1 \mathrm{H}), 1.99$ (dd, $J=15.6,8.2 \mathrm{~Hz}, 1 \mathrm{H}), 1.89(\mathrm{~d}, J=12.8 \mathrm{~Hz}, 1 \mathrm{H})$, $1.81-1.76(\mathrm{~m}, 1 \mathrm{H}), 1.75-1.64(\mathrm{~m}, 2 \mathrm{H}), 1.69-1.64(\mathrm{~m}, 2 \mathrm{H}), 1.46(\mathrm{~s}$, $3 \mathrm{H}), 1.35-1.30(\mathrm{~m}, 1 \mathrm{H}), 1.16-1.13(\mathrm{~m}, 1 \mathrm{H}), 1.14(\mathrm{~s}, 3 \mathrm{H}), 0.77(\mathrm{~s}$, $3 \mathrm{H}) ;{ }^{13} \mathrm{C} \mathrm{NMR}\left(\mathrm{CDCl}_{3}, 101 \mathrm{MHz}\right) \delta 218.1,212.1,161.0(\mathrm{~d}, J=246.3$ $\mathrm{Hz}), 146.1(\mathrm{~d}, J=3.0 \mathrm{~Hz}), 123.6,(\mathrm{~d}, J=8.8 \mathrm{~Hz}), 116.6(\mathrm{~d}, J=23.8$ $\mathrm{Hz}$ ), 61.6, 61.1, 52.4, 51.0, 47.0, 41.4, 40.7, 36.7, 34.3, 33.7, 31.0, 28.2, $21.8,20.3,18.9 ;{ }^{19} \mathrm{~F} \mathrm{NMR}\left(\mathrm{CDCl}_{3}, 282 \mathrm{MHz}\right) \delta-115.0$; IR (neat film, KBr) 3286 (br), 2959, 2927, 1737, 1704, 1500, 1464, 1384, 1360, $1191,1162,1010,987,870,849,803,736,639 \mathrm{~cm}^{-1}$; HRMS (ESI+) $m / z$ calcd for $\mathrm{C}_{23} \mathrm{H}_{31} \mathrm{NO}_{5} \mathrm{FS}[\mathrm{M}+\mathrm{H}]^{+} 452.1907$, found 452.1920; $[\alpha]_{\mathrm{D}}^{25}-32.0\left(\right.$ c 1.24, $\left.\mathrm{CHCl}_{3}\right)$.

\section{Tricyclic Azides $17 \mathrm{a}$ and $17 \mathrm{~b}$.}

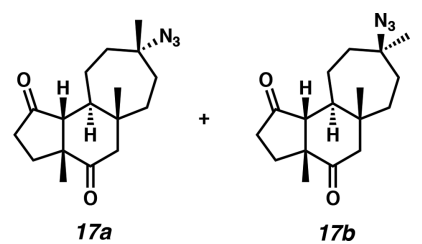

DOI: 10.1021/acs.joc.7b03291 
A flame-dried 1-dram vial was charged with known sulfonyl azide $\mathbf{1 8}$ (10.6 mg, $44.0 \mu \mathrm{mol}, 1.50$ equiv), ${ }^{46}$ potassium persulfate $(23.8 \mathrm{mg}$, $88.0 \mu \mathrm{mol}, 3.00$ equiv), and sodium bicarbonate $(2.5 \mathrm{mg}, 29.3 \mu \mathrm{mol}$, 1.00 equiv). CAUTION: AZIDES ARE POTENTIALLY EXPLOSIVE AND SHOULD BE HANDLED BEHIND SAFETY SHIELDS AND STORED IN THE FREEZER. To this mixture was added water (0.4 $\mathrm{mL})$ and a solution of tricyclic diketone $11(11.2 \mathrm{mg}, 42.5 \mu \mathrm{mol}, 1.00$ equiv) in acetonitrile $(0.6 \mathrm{~mL})$. The reaction vial was sealed with a Teflon-lined cap and heated to $85{ }^{\circ} \mathrm{C}$ using a heating mantle with vigorous stirring. After $24 \mathrm{~h}$, heating was discontinued, and the reaction mixture was diluted with ethyl acetate $(3 \mathrm{~mL})$ and water $(3$ $\mathrm{mL})$ and extracted with ethyl acetate $(3 \times 5 \mathrm{~mL})$. The combined organic extracts were dried over magnesium sulfate, and the crude residue obtained after filtration and concentration was purified by silica gel column chromatography $(10 \% \rightarrow 15 \% \rightarrow 40 \%$ ethyl acetate in hexanes) to afford diastereomers $17 \mathbf{a}(4.1 \mathrm{mg}, 32 \%$ yield) and $\mathbf{1 7} \mathbf{b}$ (7.6 mg, 58\% yield) as amorphous solids. Diastereomer 17a: $R_{f}=0.28$ (20\% ethyl acetate in hexanes); ${ }^{1} \mathrm{H}$ NMR $\left(\mathrm{CDCl}_{3}, 500 \mathrm{MHz}\right) \delta 2.61$ $(\mathrm{d}, J=15.1 \mathrm{~Hz}, 1 \mathrm{H}), 2.55-2.47(\mathrm{~m}, 1 \mathrm{H}), 2.42-2.33(\mathrm{~m}, 1 \mathrm{H}), 2.30-$ $2.22(\mathrm{~m}, 1 \mathrm{H}), 2.08(\mathrm{~d}, J=15.1 \mathrm{~Hz}, 1 \mathrm{H}), 2.01-1.94(\mathrm{~m}, 1 \mathrm{H}), 1.94-$ $1.89(\mathrm{~m}, 1 \mathrm{H}), 1.89-1.85(\mathrm{~m}, 1 \mathrm{H}), 1.80-1.74(\mathrm{~m}, 1 \mathrm{H}), 1.73-1.64(\mathrm{~m}$, $4 \mathrm{H}), 1.53(\mathrm{~m}, 1 \mathrm{H}), 1.29(\mathrm{~s}, 3 \mathrm{H}), 1.33-1.28(\mathrm{~m}, 1 \mathrm{H}), 1.13(\mathrm{~s}, 3 \mathrm{H})$, $1.15-1.10(\mathrm{~m}, 1 \mathrm{H}), 0.75(\mathrm{~s}, 3 \mathrm{H}) ;{ }^{13} \mathrm{C} \mathrm{NMR}\left(\mathrm{CDCl}_{3}, 101 \mathrm{MHz}\right) \delta$ 218.0, 212.2, 64.4, 61.3, 52.6, 51.0, 47.0, 40.8, 39.8, 37.2, 34.3, 33.2, 31.0, 27.2, 21.8, 20.7, 18.8; IR (neat film, KBr) 2960, 2923, 2097, 1732, $1704,1464,1384,1260,1142,1108,1052,802,641 \mathrm{~cm}^{-1}$; HRMS $(\mathrm{FAB}+) \mathrm{m} / z$ calcd for $\mathrm{C}_{17} \mathrm{H}_{25} \mathrm{O}_{2}\left[\mathrm{M}-\mathrm{N}_{3}\right]^{+}$261.1855, found 261.1860; $[\alpha]^{25}-59.5\left(c 0.31, \mathrm{CHCl}_{3}\right)$. Diastereomer 17b: $R_{f}=0.13$ (20\% ethyl acetate in hexanes); ${ }^{1} \mathrm{H}$ NMR $\left(\mathrm{CDCl}_{3}, 500 \mathrm{MHz}\right) \delta 2.64$ $(\mathrm{d}, J=15.2 \mathrm{~Hz}, 1 \mathrm{H}), 2.53-2.44(\mathrm{~m}, 1 \mathrm{H}), 2.43-2.33(\mathrm{~m}, 1 \mathrm{H}), 2.27-$ $2.18(\mathrm{~m}, 1 \mathrm{H}), 2.05(\mathrm{~d}, J=15.1 \mathrm{~Hz}, 1 \mathrm{H}), 1.94(\mathrm{~d}, J=12.8 \mathrm{~Hz}, 1 \mathrm{H})$, $1.92-1.84(\mathrm{~m}, 2 \mathrm{H}), 1.80-1.73(\mathrm{~m}, 1 \mathrm{H}), 1.73-1.64(\mathrm{~m}, 3 \mathrm{H}), 1.64-$ $1.60(\mathrm{~m}, 1 \mathrm{H}), 1.43-1.38(\mathrm{~m}, 1 \mathrm{H}), 1.38-1.34(\mathrm{~m}, 1 \mathrm{H}), 1.32(\mathrm{~s}, 3 \mathrm{H})$, $1.28-1.23(\mathrm{~m}, 1 \mathrm{H}), 1.14(\mathrm{~s}, 3 \mathrm{H}), 0.78(\mathrm{~s}, 3 \mathrm{H}) ;{ }^{13} \mathrm{C} \mathrm{NMR}\left(\mathrm{CDCl}_{3}\right.$, $101 \mathrm{MHz}) \delta 218.1,212.6,64.4,60.7,51.9,51.1,45.6,40.9,40.6,36.3$, 34.4, 33.0, 30.9, 28.4, 21.8, 20.6, 19.9; IR (neat film, $\mathrm{KBr}$ ) 2959, 2928, $2101,1736,1703,1458,1384,1259,1147,824 \mathrm{~cm}^{-1}$; HRMS (FAB+) $m / z$ calcd for $\mathrm{C}_{17} \mathrm{H}_{26} \mathrm{O}_{2} \mathrm{~N}_{3}[\mathrm{M}+\mathrm{H}]^{+} 304.2025$, found 304.2027; $[\alpha]^{25}{ }_{\mathrm{D}}-16.6\left(c \mathrm{co.75}, \mathrm{CHCl}_{3}\right)$.

$\mathrm{C}-\mathrm{H}$ Azidation Catalyzed by $\mathrm{Fe}(\mathrm{OAC})_{2}$. In a nitrogen-filled glovebox, iron(II) acetate $(0.4 \mathrm{mg}, 2.13 \mu \mathrm{mol}, 0.10$ equiv) and $i$-Prpybox ligand $(0.6 \mathrm{mg}, 2.13 \mu \mathrm{mol}, 0.10$ equiv) were combined in a flame-dried 1-dram vial and diluted with acetonitrile $(0.5 \mathrm{~mL})$ and stirred for $40 \mathrm{~min}$ at $23{ }^{\circ} \mathrm{C}$, generating a blue solution. After this time, a solution of tricyclic diketone $11(5.6 \mathrm{mg}, 21.3 \mu \mathrm{mol}, 1.00$ equiv) in acetonitrile $(0.5 \mathrm{~mL})$ was added, followed by known hypervalent iodine reagent 19 (12.3 mg, $42.7 \mu \mathrm{mol}, 2.00$ equiv). ${ }^{47}$ CAUTION: AZIDES ARE POTENTIALLY EXPLOSIVE AND SHOULD BE HANDLED BEHIND SAFETY SHIELDS AND STORED IN THE FREEZER. The vial was sealed with a Teflon-lined cap, and the orange mixture was stirred at $35^{\circ} \mathrm{C}$ for $4 \mathrm{~h}$, after which time the temperature was increased to $50{ }^{\circ} \mathrm{C}$ using a heating mantle. After $20 \mathrm{~h}$ at this temperature, the reaction vial was removed from the glovebox and diluted with diethyl ether $(3 \mathrm{~mL})$ and filtered through a pad of basic alumina, rinsing the filter cake with diethyl ether. The filtrate was concentrated, and the crude residue was purified by silica gel column chromatography $(10 \% \rightarrow 20 \% \rightarrow 30 \%$ ethyl acetate in hexanes), furnishing diastereomers $17 \mathrm{a}$ ( $3.1 \mathrm{mg}, 47 \%$ yield) and $17 \mathrm{~b}(2.5 \mathrm{mg}$, $39 \%$ yield) as amorphous solids that matched the characterization data reported above.

$\mathrm{C}-\mathrm{H}$ Azidation Mediated by Benzoyl Peroxide. In a nitrogen-filled glovebox, benzoyl peroxide $\left(0.5 \mathrm{mg}, 2.21 \mu \mathrm{mol}, 0.10\right.$ equiv) and $1,1^{\prime}$ azobis(cyclohexanecarbonitrile) $(0.3 \mathrm{mg}, 1.11 \mu \mathrm{mol}, 0.05$ equiv) were combined in a flame-dried 1-dram vial and diluted with 1,2dichloroethane $(0.5 \mathrm{~mL})$. A solution of tricyclic diketone 11 (5.8 $\mathrm{mg}, 22.1 \mu \mathrm{mol}, 1.00$ equiv $)$ in 1,2-dichloroethane $(0.6 \mathrm{~mL})$ was added, followed by known hypervalent iodine reagent 19 (12.8 mg, 44.2 $\mu$ mol, 2.00 equiv), ${ }^{47}$ and the vial was sealed with a Teflon-lined cap and heated to $84{ }^{\circ} \mathrm{C}$ using a heating mantle. After $24 \mathrm{~h}$, the reaction vial was removed from the glovebox, and the reaction mixture was filtered through a pad of basic alumina, rinsing with diethyl ether, and the filtrate was concentrated. The resulting crude residue was purified by silica gel column chromatography $(10 \% \rightarrow 15 \% \rightarrow 40 \%$ ethyl acetate in hexanes), delivering tricyclic azide $\mathbf{1 7 b}$ as an amorphous solid $(0.9 \mathrm{mg}, 13 \%$ yield $)$ that matched the characterization data reported above.

Chlorinated Diketone 20.

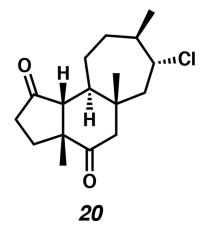

In a flame-dried 1-dram vial, tricyclic diketone $11(5.0 \mathrm{mg}, 19.1$ $\mu \mathrm{mol}, 1.00$ equiv) was diluted with dry benzene $(0.50 \mathrm{~mL})$ and concentrated under reduced pressure. This azeotropic drying procedure was repeated twice more before drying under high vacuum ( 0.65 Torr) for $10 \mathrm{~min}$. The vial was wrapped with foil and brought into a nitrogen-filled glovebox, and a solution of $\mathrm{N}$-chloroamide $\mathbf{2 1}$ (6.6 $\mathrm{mg}, 19.1 \mu \mathrm{mol}, 1.00$ equiv) in benzene $(0.30 \mathrm{~mL})$ was added, followed by cesium carbonate $(6.2 \mathrm{mg}, 19.1 \mu \mathrm{mol}, 1.00$ equiv). The vial was sealed with a Teflon-lined cap, removed from the glovebox, and heated to $55^{\circ} \mathrm{C}$ in heating block after removing the foil from the reaction vial (note: fume hood lights turned off). Once this temperature had been reached, the reaction vial was irradiated with two $23 \mathrm{~W}$ CFL bulbs positioned $5 \mathrm{~cm}$ from either side of the heating block. After $24 \mathrm{~h}$, the reaction was removed from heat and immediately diluted with dichloromethane $(2 \mathrm{~mL})$ and filtered over a plug of silica gel, rinsing with dichloromethane. Concentration of the filtrate and purification of the crude residue by silica gel column chromatography $(7 \% \rightarrow 10 \% \rightarrow 20 \%$ ethyl acetate in hexanes $)$ afforded chlorinated tricycle $\mathbf{2 0}$ as a colorless oil ( $1.7 \mathrm{mg}, 30 \%$ yield): $R_{f}=0.25$ (20\% ethyl acetate in hexanes); ${ }^{1} \mathrm{H} \mathrm{NMR}\left(\mathrm{CDCl}_{3}, 500\right.$ $\mathrm{MHz}) \delta 3.84(\mathrm{t}, J=9.5,19.1 \mathrm{~Hz}, 1 \mathrm{H}), 2.67(\mathrm{~d}, J=15.1 \mathrm{~Hz}, 1 \mathrm{H})$, $2.55-2.47(\mathrm{~m}, 1 \mathrm{H}), 2.42-2.33(\mathrm{~m}, 1 \mathrm{H}), 2.31-2.23(\mathrm{~m}, 1 \mathrm{H}), 2.22-$ $2.11(\mathrm{~m}, 3 \mathrm{H}), 1.97-1.89(\mathrm{~m}, 1 \mathrm{H}), 1.89-1.83(\mathrm{~m}, 2 \mathrm{H}), 1.81-1.74(\mathrm{~m}$, $1 \mathrm{H}), 1.74-1.62(\mathrm{~m}, 3 \mathrm{H}), 1.20-1.16(\mathrm{~m}, 1 \mathrm{H}), 1.14(\mathrm{~s}, 3 \mathrm{H}), 1.12(\mathrm{~d}, J$ $=6.9 \mathrm{~Hz}, 3 \mathrm{H}), 0.85(\mathrm{~s}, 3 \mathrm{H}) ;{ }^{13} \mathrm{C} \mathrm{NMR}\left(\mathrm{CDCl}_{3}, 101 \mathrm{MHz}\right) \delta 217.9$, $211.9,63.9,61.3,52.7,50.9,50.8,46.6,41.3,41.0,34.3,32.8,31.1$, 21.7, 21.3, 20.2, 18.5; IR (neat film, KBr) 3361, 3194, 2922, 2960, 2853, 1732, 1738, 1704, 1469, 1456, 1384, 1261, 1106, 1052, 1023, 800, 764, $705 \mathrm{~cm}^{-1}$; HRMS (EI+) $\mathrm{m} / z$ calcd for $\mathrm{C}_{17} \mathrm{H}_{25} \mathrm{ClO}_{2}\left[\mathrm{M}^{\bullet}\right]^{+}$ 296.1543, found 296.1550; $[\alpha]_{\mathrm{D}}^{25}-24.6\left(c 0.17, \mathrm{CHCl}_{3}\right)$.

\section{ASSOCIATED CONTENT}

S Supporting Information

The Supporting Information is available free of charge on the ACS Publications website at DOI: 10.1021/acs.joc.7b03291.

NMR spectra of all new compounds (PDF)

Crystallographic data for $\mathbf{1 1}$ (CIF)

\section{AUTHOR INFORMATION}

\section{Corresponding Author}

*E-mail: stoltz@caltech.edu.

ORCID $\odot$

Nicholas D. Chiappini: 0000-0003-0469-1008

Brian M. Stoltz: 0000-0001-9837-1528

Notes

The authors declare no competing financial interest.

\section{ACKNOWLEDGMENTS}

This work was supported by the NSF under the CCI Center for Selective C-H Functionalization (CCHF), CHE-1700982. Additional financial support was provided by Caltech and Novartis. Dr. Xiangyou Xing and members of the CCHF are 
acknowledged for helpful discussions. The White group (UIUC) and the Sarpong group (UC Berkeley) are thanked for supplying the $\mathrm{Fe}\left(R, R-\mathrm{CF}_{3}-\mathrm{PDP}\right)$ and $\mathrm{Fe}(S, S-\mathrm{PDP})$ catalysts, respectively. Dr. David VanderVelde (NMR), Dr. Mona Shahgholi and Naseem Torian (HRMS), and Dr. Michael K. Takase and Niklas Thompson (X-ray crystallography) are acknowledged for assistance with structural determination and characterization.

\section{REFERENCES}

(1) Arndtsen, B. A.; Bergman, R. G.; Mobley, T. A.; Peterson, T. H. Acc. Chem. Res. 1995, 28, 154-162.

(2) For reviews on $\mathrm{C}-\mathrm{H}$ functionalization in natural product synthesis, see: (a) Newhouse, T.; Baran, P. S. Angew. Chem., Int. Ed. 2011, 50, 3362-3374. (b) Gutekunst, W. R.; Baran, P. S. Chem. Soc. Rev. 2011, 40, 1976-1991. (c) McMurray, L.; O’Hara, F.; Gaunt, M. J. Chem. Soc. Rev. 2011, 40, 1885-1898. (d) Chen, D. Y.-K.; Youn, S. W. Chem. - Eur. J. 2012, 18, 9452-9474. (e) Kuttruff, C. A.; Eastgate, M. D.; Baran, P. S. Nat. Prod. Rep. 2014, 31, 419-432. (f) Noisier, A. F. M.; Brimble, M. A. Chem. Rev. 2014, 114, 8775-8806. (g) Qiu, Y.; Gao, S. Nat. Prod. Rep. 2016, 33, 562-581.

(3) (a) Wencel-Delord, J.; Glorius, F. Nat. Chem. 2013, 5, 369-375. (b) Cernak, T.; Dykstra, K. D.; Tyagarajan, S.; Vachal, P.; Krska, S. W. Chem. Soc. Rev. 2016, 45, 546-576.

(4) (a) Dai, H.-X.; Stepan, A. F.; Plummer, M. S.; Zhang, Y.-H.; Yu, J.-Q. J. Am. Chem. Soc. 2011, 133, 7222-7228. (b) Meyer, C.; Schepmann, D.; Yanagisawa, S.; Yamaguchi, J.; Itami, K.; Wünsch, B. Eur. J. Org. Chem. 2012, 2012, 5972-5979.

(5) Beydoun, K.; Zaarour, M.; Williams, J. A. G.; Doucet, H.; Guerchais, V. Chem. Commun. 2012, 48, 1260-1262.

(6) Dröge, T.; Notzon, A.; Fröhlich, R.; Glorius, F. Chem. - Eur. J. 2011, 17, 11974-11977.

(7) (a) Kondo, Y.; García-Cuadrado, D.; Hartwig, J. F.; Boaen, N. K.; Wagner, N. L.; Hillmyer, M. A. J. Am. Chem. Soc. 2002, 124, 11641165. (b) Jo, T. S.; Kim, S. H.; Shin, J.; Bae, C. J. Am. Chem. Soc. 2009, 131, 1656-1657.

(8) He, J.; Hamann, L. G.; Davies, H. M. L.; Beckwith, R. E. J. Nat. Commun. 2015, 6, 5943.

(9) Adams, A. M.; Du Bois, J.; Malik, H. A. Org. Lett. 2015, 17, 6066-6069.

(10) Michaudel, Q.; Journot, G.; Regueiro-Ren, A.; Goswami, A.; Guo, Z.; Tully, T. P.; Zou, L.; Ramabhadran, R. O.; Houk, K. N.; Baran, P. S. Angew. Chem., Int. Ed. 2014, 53, 12091-12096.

(11) For studies on $\mathrm{C}\left({ }_{\mathrm{sp}} 3\right)-\mathrm{H}$ oxidation of terpenoid scaffolds, see: (a) Pitts, C. R.; Bume, D. D.; Harry, S. A.; Siegler, M. A.; Lectka, T. J. Am. Chem. Soc. 2017, 139, 2208-2211. (b) Xu, S.-H.; Wang, W.-W.; Zhang, C.; Liu, X.-F.; Yu, B.-Y. Tetrahedron 2017, 73, 3086-3092.

(12) For a study of the biological properties of ingenol derivatives access via $\mathrm{C}\left(\mathrm{sp}^{3}\right)-\mathrm{H}$ oxidation, see: Jin, Y.; Yeh, C.-H.; Kuttruff, C. A.; Jørgensen, L.; Dünstl, G.; Felding, J.; Natarajan, S. R.; Baran, P. S. Angew. Chem., Int. Ed. 2015, 54, 14044-14048.

(13) Shugrue, C. R.; Miller, S. J. Chem. Rev. 2017, 117, 1189411951.

(14) (a) Enquist, J. A., Jr.; Stoltz, B. M. Nature 2008, 453, 12281231. (b) Enquist, J. A., Jr.; Virgil, S. C.; Stoltz, B. M. Chem. - Eur. J. 2011, 17, 9957-9969. (c) Kim, K. E.; Stoltz, B. M. Org. Lett. 2016, 18, $5720-5723$.

(15) (a) Lyons, T. W.; Sanford, M. S. Chem. Rev. 2010, 110, 11471169. (b) Zhang, M.; Zhang, Y.; Jie, X.; Zhao, H.; Li, G.; Su, W. Org. Chem. Front. 2014, 1, 843-895.

(16) Sakuda, Y. Bull. Chem. Soc. Jpn. 1969, 42, 3348-3349.

(17) (a) Ernet, T.; Haufe, G. Synthesis 1997, 1997, 953-956. (b) Umbreit, M. A.; Sharpless, K. B. J. Am. Chem. Soc. 1977, 99, 55265528 .

(18) Młochowski, J.; Wójtowicz-Młochowska, H. Molecules 2015, 20, 10205-10243.

(19) Campbell, A. N.; White, P. B.; Guzei, I. A.; Stahl, S. S. J. Am. Chem. Soc. 2010, 132, 15116-15119.
(20) Chen, M. S.; White, M. C. J. Am. Chem. Soc. 2004, 126, 13461347.

(21) Xing, X.; O'Connor, N. R.; Stoltz, B. M. Angew. Chem., Int. Ed. 2015, 54, 11186-11190.

(22) Efforts to effect Pd-catalyzed allylic $\mathrm{C}-\mathrm{H}$ azidation proved unsuccessful, returning unreacted 6. For experimental conditions, see: Chen, H.; Yang, W.; Wu, W.; Jiang, H. Org. Biomol. Chem. 2014, 12, 3340-3343.

(23) For the unsuccessful allylic acetoxylation experimental procedures, see the Supporting Information.

(24) Application of Ru-catalyzed conditions for $\mathrm{C}-\mathrm{H}$ hydroxylation to 6 resulted in epoxidation of the C-ring olefin.

(25) Lowering the temperature below $0{ }^{\circ} \mathrm{C}$ did not result in further increased dr.

(26) McNeill, E.; Du Bois, J. J. Am. Chem. Soc. 2010, 132, 1020210204

(27) McNeill, E.; Du Bois, J. Chem. Sci. 2012, 3, 1810-1813.

(28) Adams, A. M.; Du Bois, J. Chem. Sci. 2014, 5, 656-659.

(29) For selected examples of dioxiranes as reagents for $\mathrm{C}-\mathrm{H}$ hydroxylation, see: (a) Curci, R.; D'Accolti, L.; Fusco, C. Acc. Chem. Res. 2006, 39, 1-9. (b) Chen, K.; Baran, P. S. Nature 2009, 459, 824828. For a study of the molecular dynamics of DMDO $\mathrm{C}-\mathrm{H}$ oxidation, see: (c) Yang, Z.; Yu, P.; Houk, K. N. J. Am. Chem. Soc. 2016, 138, 4237-4242.

(30) Chen, M. S.; White, M. C. Science 2007, 318, 783-787.

(31) Gormisky, P. E.; White, M. C. J. Am. Chem. Soc. 2013, 135, 14052-14055.

(32) Salamone, M.; Ortega, V. B.; Bietti, M. J. Org. Chem. 2015, 80, $4710-4715$.

(33) (a) Henkel, T.; Brunne, R. M.; Müller, H.; Reichel, F. Angew. Chem., Int. Ed. 1999, 38, 643-647. (b) Hili, R.; Yudin, A. K. Nat. Chem. Biol. 2006, 2, 284-287.

(34) Roizen, J. L.; Zalatan, D. N.; Du Bois, J. Angew. Chem., Int. Ed. 2013, 52, 11343-11346.

(35) Chiappini, N. D.; Mack, J. B. C.; Du Bois, J. Manuscript submitted for publication.

(36) (a) Gaoni, Y. J. Org. Chem. 1994, 59, 6853-6855. (b) Scriven, E. F. V.; Turnbull, K. Chem. Rev. 1988, 88, 297-368.

(37) Zhang, X.; Yang, H.; Tang, P. Org. Lett. 2015, 17, 5828-5831.

(38) (a) Sharma, A.; Hartwig, J. F. Nature 2015, 517, 600-604. (b) Karimov, R. R.; Sharma, A.; Hartwig, J. F. ACS Cent. Sci. 2016, 2, $715-724$.

(39) Another method for $\mathrm{C}-\mathrm{H}$ azidation was explored but did not provide conclusive results. For experimental conditions, see: Huang, X.; Bergsten, T. M.; Groves, J. T. J. Am. Chem. Soc. 2015, 137, 53005303.

(40) Protocols for $\mathrm{C}-\mathrm{H}$ fluorination yielded either irreproducible results or extremely low conversion. For experimental conditions, see: (a) Xia, J.-B.; Ma, Y.; Chen, C. Org. Chem. Front. 2014, 1, 468-472. (b) West, J. G.; Bedell, T. A.; Sorensen, E. J. Angew. Chem., Int. Ed. 2016, 55, 8923-8927.

(41) For another method for $\mathrm{C}-\mathrm{H}$ chlorination, see: (a) Liu, W.; Groves, J. T. J. Am. Chem. Soc. 2010, 132, 12847-12849. (b) Liu, W.; Groves, J. T. Acc. Chem. Res. 2015, 48, 1727-1735.

(42) Quinn, R. K.; Könst, Z. A.; Michalak, S. E.; Schmidt, Y.; Szklarski, A. R.; Flores, A. R.; Nam, S.; Horne, D. A.; Vanderwal, C. D.; Alexanian, E. J. J. Am. Chem. Soc. 2016, 138, 696-702.

(43) Indicated by mass spectrometry.

(44) For selected reviews on this topic, see: (a) Brückl, T.; Baxter, R. D.; Ishihara, Y.; Baran, P. S. Acc. Chem. Res. 2012, 45, 826-839. (b) Doyle, M. P.; Duffy, R.; Ratnikov, M.; Zhou, L. Chem. Rev. 2010, 110, 704-724. (c) Roizen, J. L.; Harvey, M. E.; Du Bois, J. Acc. Chem. Res. 2012, 45, 911-922. (d) Du Bois, J. Chemtracts Org. Chem. 2005, 18, 1-13. (e) White, M. C. Science 2012, 335, 807-809.

(45) Taber, D. F.; DeMatteo, P. W.; Hassan, R. A. Org. Synth. 2013, 90, 350-357.

(46) Waser, J.; Gaspar, B.; Nambu, H.; Carreira, E. M. J. Am. Chem. Soc. 2006, 128, 11693-11712.

(47) Vita, M. V.; Waser, J. Org. Lett. 2013, 15, 3246-3249. 
(48) Brodsky, B. H.; Du Bois, J. J. Am. Chem. Soc. 2005, 127, 1539115393. 